\title{
An Update on Antitumor Activity of Naturally Occurring Chalcones
}

\author{
En-Hui Zhang, ${ }^{1}$ Ru-Feng Wang, ${ }^{1}$ Shu-Zhen Guo, ${ }^{2}$ and Bin Liu ${ }^{1}$ \\ ${ }^{1}$ School of Chinese Medicine, Beijing University of Chinese Medicine, Beijing 100102, China \\ ${ }^{2}$ School of Preclinical Medicine, Beijing University of Chinese Medicine, Beijing 100029, China \\ Correspondence should be addressed to Bin Liu; liubinyn67@163.com
}

Received 15 January 2013; Accepted 19 March 2013

Academic Editor: Yoshiyuki Kimura

Copyright (c) 2013 En-Hui Zhang et al. This is an open access article distributed under the Creative Commons Attribution License, which permits unrestricted use, distribution, and reproduction in any medium, provided the original work is properly cited.

\begin{abstract}
Chalcones, which have characteristic 1,3-diaryl-2-propen-1-one skeleton, are mainly produced in roots, rhizomes, heartwood, leaves, and seeds of genera Angelica, Sophora, Glycyrrhiza, Humulus, Scutellaria, Parartocarpus, Ficus, Dorstenia, Morus, Artocarpus, and so forth. They have become of interest in the research and development of natural antitumor agents over the past decades due to their broad range of mechanisms including anti-initiation, induction of apoptosis, antiproliferation, antimetastasis, antiangiogenesis, and so forth. This review summarizes the studies on the antitumor activity of naturally occurring chalcones and their underlying mechanisms in detail during the past decades.
\end{abstract}

\section{Introduction}

Chalcones are one of the subclasses of flavonoid family. They are commonly known as yellow pigments in flowers, and are also widely distributed in various parts (roots, rhizomes, heartwood, buds, leaves, flowers, and seeds) of species of genera Angelica, Sophora, Glycyrrhiza, Humulus, Scutellaria, Parartocarpus, Ficus, Dorstenia, Morus, Artocarpus, and so forth. A wide range of biological activities have been attributed to chalcones, including antitumor, antimutagenic, anti-inflammatory, antioxidant, antifungal, antibacterial, antiprotozoal, analgesic, and gastric protective properties [1]. As for antitumor activity, chalcones exhibit various effects including anti-initiation, apoptosis induction, antiproliferation, antimetastasis, antiangiogenesis, and so forth. This review summarizes the studies on the antitumor activity of naturally occurring chalcones and their underlying mechanisms in detail during the past decade and also briefly categorized these compounds on the basis of their structures.

\section{Structures}

Chalcones, a term introduced by Kostanecki and Tabor [2], are considered as the precursors of flavones in the biosynthesis of flavonoids. Structurally, they are a group of compounds bearing 1,3-diaryl-2-propen-1-one framework, which consists of open-chain flavonoids in which the two aromatic rings are joined together by three carbons in an $\alpha, \beta$ unsaturated system. Chemically, they can be easily cyclized by a Michael addition at the $\beta$ position of the carbonyl to form a flavanone. The existence of double bond results in cis and trans isomeric forms of chalcone in nature, of which the trans form is thermodynamically stable. Chalcone is one of the most structurally diverse groups of flavonoids existing as dimmers, oligomers, Diels-Alder adducts, and conjugates of various kinds. Additionally, the attachment of varieties of hydroxyl, methoxy, and alkenyl functionalities to the framework of chalcone contributes to its structural diversity as well [3].

During the last decade, about 90 compounds of chalcones with various antitumor activities were reported. They can be roughly categorized into 4 large groups, namely, chalcones with $O$-substitution, prenylated chalcones, Diels-Alder adducts, and others. All these 90 compounds are shown in Figure 1.

2.1. Chalcones with O-Substitution. This group of compounds (1-26) carries a varying number of $O$-substituents on A-ring 
<smiles>O=C(/C=C/c1ccccc1)c1ccccc1</smiles>

\begin{tabular}{|c|c|c|c|c|c|c|c|c|c|c|}
\hline & $2^{\prime}$ & $3^{\prime}$ & $4^{\prime}$ & $5^{\prime}$ & $6^{\prime}$ & 2 & 3 & 4 & 5 & 6 \\
\hline 1 & $\mathrm{H}$ & $\mathrm{H}$ & $\mathrm{OH}$ & $\mathrm{H}$ & $\mathrm{OH}$ & $\mathrm{H}$ & $\mathrm{OH}$ & $\mathrm{OH}$ & $\mathrm{H}$ & $\mathrm{H}$ \\
\hline 2 & $\mathrm{OCH}_{3}$ & $\mathrm{H}$ & $\mathrm{OCH}_{3}$ & $\mathrm{H}$ & $\mathrm{OH}$ & $\mathrm{H}$ & $\mathrm{H}$ & $\mathrm{H}$ & $\mathrm{H}$ & $\mathrm{H}$ \\
\hline 3 & $\mathrm{OH}$ & $\mathrm{H}$ & $\mathrm{OCH}_{3}$ & $\mathrm{H}$ & $\mathrm{OH}$ & $\mathrm{H}$ & $\mathrm{H}$ & $\mathrm{H}$ & $\mathrm{H}$ & $\mathrm{H}$ \\
\hline 4 & $\mathrm{OH}$ & $\mathrm{H}$ & $\mathrm{OH}$ & $\mathrm{H}$ & $\mathrm{H}$ & $\mathrm{H}$ & $\mathrm{OCH}_{3}$ & $\mathrm{OCH}_{3}$ & $\mathrm{H}$ & $\mathrm{H}$ \\
\hline 5 & $\mathrm{OH}$ & $\mathrm{H}$ & $\mathrm{OH}$ & $\mathrm{H}$ & $\mathrm{H}$ & $\mathrm{OCH}_{3}$ & $\mathrm{OCH}_{3}$ & $\mathrm{H}$ & $\mathrm{H}$ & $\mathrm{H}$ \\
\hline 6 & $\mathrm{OH}$ & $\mathrm{H}$ & $\mathrm{OH}$ & $\mathrm{H}$ & $\mathrm{H}$ & $\mathrm{H}$ & $\mathrm{H}$ & $\mathrm{OCH}_{3}$ & $\mathrm{H}$ & $\mathrm{H}$ \\
\hline 7 & $\mathrm{OH}$ & $\mathrm{CH}_{3}$ & $\mathrm{OH}$ & $\mathrm{CH}_{3}$ & $\mathrm{OCH}_{3}$ & $\mathrm{H}$ & $\mathrm{H}$ & $\mathrm{H}$ & $\mathrm{H}$ & $\mathrm{H}$ \\
\hline 8 & $\mathrm{OCH}_{3}$ & $\mathrm{H}$ & $\mathrm{OH}$ & $\mathrm{CH}_{3}$ & $\mathrm{OH}$ & $\mathrm{H}$ & $\mathrm{H}$ & $\mathrm{H}$ & $\mathrm{H}$ & $\mathrm{H}$ \\
\hline 9 & $\mathrm{OCH}_{3}$ & $\mathrm{H}$ & $\mathrm{OH}$ & $\mathrm{H}$ & $\mathrm{OH}$ & $\mathrm{H}$ & $\mathrm{H}$ & $\mathrm{H}$ & $\mathrm{H}$ & $\mathrm{H}$ \\
\hline 10 & $\mathrm{OH}$ & $\mathrm{H}$ & $\mathrm{OH}$ & $\mathrm{H}$ & $\mathrm{H}$ & $\mathrm{H}$ & $\mathrm{H}$ & $\mathrm{H}$ & $\mathrm{H}$ & $\mathrm{H}$ \\
\hline 11 & $\mathrm{OCH}_{3}$ & $\mathrm{H}$ & $\mathrm{OH}$ & $\mathrm{H}$ & $\mathrm{H}$ & $\mathrm{H}$ & $\mathrm{H}$ & $\mathrm{OH}$ & $\mathrm{H}$ & $\mathrm{H}$ \\
\hline 12 & $\mathrm{OH}$ & $\mathrm{H}$ & $\mathrm{OH}$ & $\mathrm{H}$ & $\mathrm{H}$ & $\mathrm{H}$ & $\mathrm{H}$ & $\mathrm{OH}$ & $\mathrm{H}$ & $\mathrm{H}$ \\
\hline 13 & $\mathrm{OH}$ & $\mathrm{H}$ & $\mathrm{OCH}_{3}$ & $\mathrm{H}$ & $\mathrm{OCH}_{3}$ & $\mathrm{H}$ & $\mathrm{H}$ & $\mathrm{OH}$ & $\mathrm{H}$ & $\mathrm{H}$ \\
\hline 14 & $\mathrm{OH}$ & $\mathrm{H}$ & $\mathrm{OCH}_{3}$ & $\mathrm{H}$ & $\mathrm{OH}$ & $\mathrm{H}$ & $\mathrm{H}$ & $\mathrm{H}$ & $\mathrm{H}$ & $\mathrm{H}$ \\
\hline 15 & $\mathrm{H}$ & $\mathrm{OH}$ & $\mathrm{OH}$ & $\mathrm{H}$ & $\mathrm{H}$ & $\mathrm{OCH}_{3}$ & $\mathrm{H}$ & $\mathrm{OH}$ & $\mathrm{H}$ & $\mathrm{OCH}_{3}$ \\
\hline 16 & $\mathrm{OCH}_{3}$ & $\mathrm{H}$ & $\mathrm{OCH}_{3}$ & $\mathrm{H}$ & $\mathrm{OH}$ & $\mathrm{H}$ & $\mathrm{H}$ & $\mathrm{OCH}_{3}$ & $\mathrm{H}$ & $\mathrm{H}$ \\
\hline 17 & $\mathrm{OCH}_{3}$ & $\mathrm{H}$ & $\mathrm{OCH}_{3}$ & $\mathrm{H}$ & $\mathrm{OH}$ & $\mathrm{H}$ & $\mathrm{H}$ & $\mathrm{OH}$ & $\mathrm{H}$ & $\mathrm{H}$ \\
\hline 18 & $\mathrm{O}-\beta$-D-Glc & $\mathrm{H}$ & $\mathrm{OH}$ & $\mathrm{H}$ & $\mathrm{OH}$ & $\mathrm{H}$ & $\mathrm{H}$ & $\mathrm{OH}$ & $\mathrm{H}$ & $\mathrm{H}$ \\
\hline 19 & $\mathrm{OH}$ & $\mathrm{H}$ & $\mathrm{OH}$ & $\mathrm{H}$ & $\mathrm{OH}$ & $\mathrm{H}$ & $\mathrm{H}$ & $\mathrm{OH}$ & $\mathrm{H}$ & $\mathrm{H}$ \\
\hline 20 & $\mathrm{OCH}_{3}$ & $\mathrm{H}$ & $\mathrm{OH}$ & $\mathrm{CHO}$ & $\mathrm{OH}$ & $\mathrm{H}$ & $\mathrm{H}$ & $\mathrm{H}$ & $\mathrm{H}$ & $\mathrm{H}$ \\
\hline 21 & $\mathrm{OH}$ & $\mathrm{H}$ & $\mathrm{OCH}_{3}$ & $\mathrm{H}$ & $\mathrm{OCH}_{3}$ & $\mathrm{OCH}_{3}$ & $\mathrm{OCH}_{3}$ & $\mathrm{H}$ & $\mathrm{H}$ & $\mathrm{H}$ \\
\hline
\end{tabular}

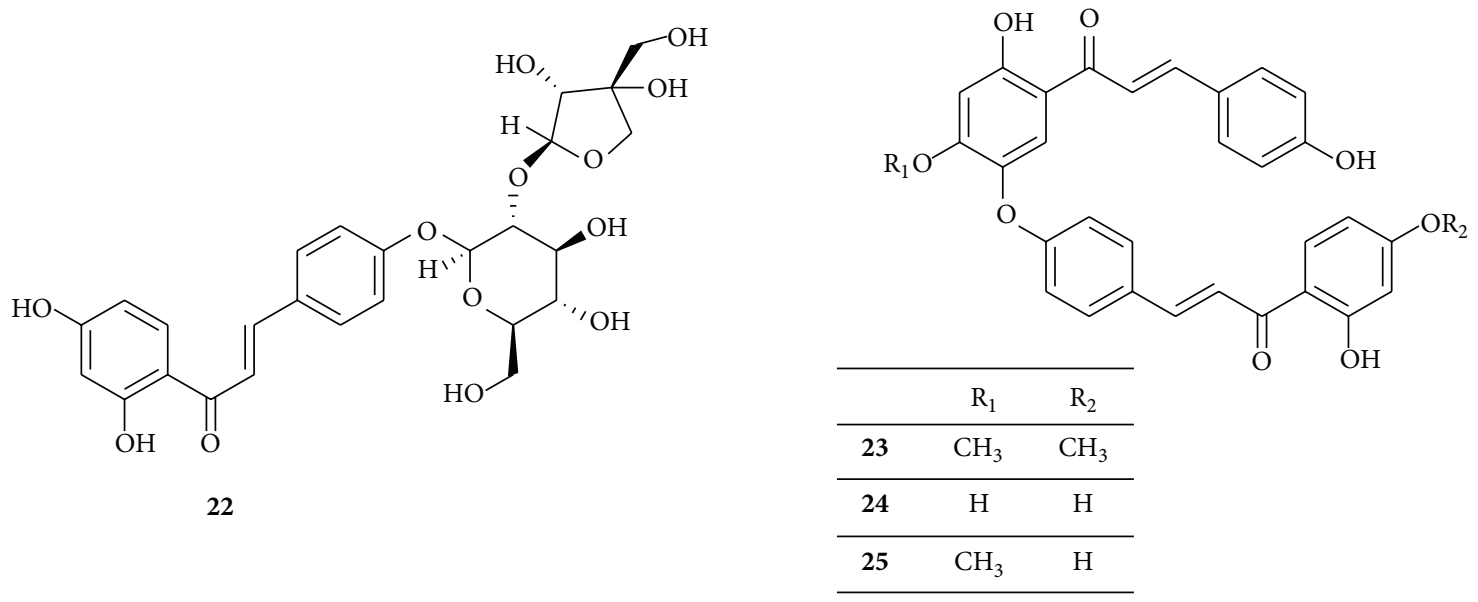

(a)

Figure 1: Continued. 
<smiles>COc1cc(O)c(C(=O)/C=C/c2ccc(O)cc2)cc1Oc1ccc(C(=O)/C=C/c2ccc(O)cc2)c(O)c1</smiles><smiles>O=C(/C=C/c1ccccc1)c1ccccc1</smiles>

\begin{tabular}{|c|c|c|c|c|c|c|c|c|c|c|}
\hline & $2^{\prime}$ & $3^{\prime}$ & $4^{\prime}$ & $5^{\prime}$ & $6^{\prime}$ & 2 & 3 & 4 & 5 & 6 \\
\hline 27 & $\mathrm{H}$ & $\mathrm{H}$ & $\mathrm{OH}$ & $\mathrm{H}$ & $\mathrm{OH}$ & $\mathrm{H}$ & Pre & $\mathrm{OH}$ & $\mathrm{OCH}_{3}$ & $\mathrm{H}$ \\
\hline 28 & $\mathrm{OCH}_{3}$ & $\mathrm{H}$ & $\mathrm{OH}$ & Ger & $\mathrm{OH}$ & $\mathrm{H}$ & $\mathrm{H}$ & $\mathrm{H}$ & $\mathrm{H}$ & $\mathrm{H}$ \\
\hline 29 & $\mathrm{OH}$ & Ger & $\mathrm{OH}$ & $\mathrm{H}$ & $\mathrm{OH}$ & $\mathrm{H}$ & $\mathrm{H}$ & $\mathrm{OH}$ & $\mathrm{H}$ & $\mathrm{H}$ \\
\hline 30 & $\mathrm{OH}$ & Pre & $\mathrm{OH}$ & Pre & $\mathrm{OCH}_{3}$ & $\mathrm{H}$ & $\mathrm{H}$ & $\mathrm{OH}$ & $\mathrm{H}$ & $\mathrm{H}$ \\
\hline 31 & $\mathrm{OH}$ & & $\mathrm{OH}$ & $\mathrm{H}$ & $\mathrm{OCH}_{3}$ & $\mathrm{H}$ & $\mathrm{H}$ & $\mathrm{OH}$ & $\mathrm{H}$ & $\mathrm{H}$ \\
\hline 32 & $\mathrm{OH}$ & Pre & $\mathrm{OH}$ & $\mathrm{H}$ & $\mathrm{OH}$ & $\mathrm{H}$ & $\mathrm{H}$ & $\mathrm{OH}$ & $\mathrm{H}$ & $\mathrm{H}$ \\
\hline 33 & $\mathrm{OH}$ & Pre & $\mathrm{OCH}_{3}$ & $\mathrm{H}$ & $\mathrm{OH}$ & $\mathrm{H}$ & $\mathrm{H}$ & $\mathrm{OH}$ & $\mathrm{H}$ & $\mathrm{H}$ \\
\hline 34 & $\mathrm{OH}$ & Pre & $\mathrm{OCH}_{3}$ & $\mathrm{H}$ & $\mathrm{OCH}_{3}$ & $\mathrm{H}$ & $\mathrm{H}$ & $\mathrm{OH}$ & $\mathrm{H}$ & $\mathrm{H}$ \\
\hline 35 & $\mathrm{H}$ & $\mathrm{H}$ & $\mathrm{OH}$ & $\mathrm{H}$ & $\mathrm{H}$ & $\mathrm{H}$ & & $\mathrm{OH}$ & $\mathrm{H}$ & $\mathrm{OCH} 3$ \\
\hline 36 & $\mathrm{H}$ & $\mathrm{H}$ & $\mathrm{OH}$ & $\mathrm{H}$ & $\mathrm{H}$ & $\mathrm{H}$ & $\mathrm{H}$ & $\mathrm{OH}$ & & $\mathrm{OCH}_{3}$ \\
\hline 37 & $\mathrm{H}$ & $\mathrm{H}$ & $\mathrm{OH}$ & $\mathrm{H}$ & $\mathrm{H}$ & $\mathrm{H}$ & & $\mathrm{OH}$ & $\mathrm{H}$ & $\mathrm{OCH}_{3}$ \\
\hline 38 & $\mathrm{OH}$ & Pre & $\mathrm{OH}$ & $\mathrm{H}$ & $\mathrm{OCH}_{3}$ & $\mathrm{OH}$ & $\mathrm{H}$ & $\mathrm{OH}$ & $\mathrm{H}$ & $\mathrm{H}$ \\
\hline 39 & $\mathrm{H}$ & Ger & $\mathrm{OH}$ & $\mathrm{H}$ & $\mathrm{OH}$ & $\mathrm{H}$ & $\mathrm{H}$ & $\mathrm{OH}$ & $\mathrm{H}$ & $\mathrm{H}$ \\
\hline 40 & $\mathrm{H}$ & $\mathrm{H}$ & $\mathrm{OH}$ & Pre & $\mathrm{OH}$ & $\mathrm{H}$ & $\mathrm{H}$ & $\mathrm{H}$ & $\mathrm{H}$ & $\mathrm{H}$ \\
\hline 41 & $\mathrm{H}$ & $\mathrm{H}$ & $\mathrm{OCH}_{3}$ & Pre & $\mathrm{OH}$ & $\mathrm{H}$ & $\mathrm{H}$ & $\mathrm{H}$ & $\mathrm{H}$ & $\mathrm{H}$ \\
\hline 42 & $\mathrm{OH}$ & Pre & $\mathrm{OH}$ & $\mathrm{H}$ & $\mathrm{H}$ & $\mathrm{H}$ & $\mathrm{H}$ & $\mathrm{OH}$ & $\mathrm{H}$ & $\mathrm{H}$ \\
\hline 43 & $\mathrm{OH}$ & & $\mathrm{OCH}_{3}$ & $\mathrm{H}$ & $\mathrm{H}$ & $\mathrm{H}$ & $\mathrm{H}$ & $\mathrm{OH}$ & $\mathrm{H}$ & $\mathrm{H}$ \\
\hline 44 & $\mathrm{H}$ & $\mathrm{H}$ & $\mathrm{OH}$ & Ger & $\mathrm{OH}$ & $\mathrm{H}$ & $\mathrm{H}$ & $\mathrm{OH}$ & $\mathrm{H}$ & $\mathrm{H}$ \\
\hline 45 & $\mathrm{OH}$ & Pre & $\mathrm{OH}$ & $\mathrm{H}$ & $\mathrm{H}$ & $\mathrm{H}$ & Pre & $\mathrm{OH}$ & $\mathrm{H}$ & $\mathrm{H}$ \\
\hline 46 & $\mathrm{OH}$ & $\mathrm{H}$ & $\mathrm{OH}$ & Pre & $\mathrm{H}$ & $\mathrm{H}$ & Pre & $\mathrm{OH}$ & $\mathrm{H}$ & $\mathrm{H}$ \\
\hline 47 & $\mathrm{H}$ & $\mathrm{H}$ & $\mathrm{OCH}_{3}$ & Pre & $\mathrm{OH}$ & $\mathrm{H}$ & $\mathrm{H}$ & $\mathrm{OH}$ & $\mathrm{H}$ & $\mathrm{H}$ \\
\hline 48 & $\mathrm{H}$ & $\mathrm{H}$ & $\mathrm{OCH}_{3}$ & Ger & $\mathrm{OH}$ & $\mathrm{H}$ & $\mathrm{H}$ & $\mathrm{OH}$ & $\mathrm{H}$ & $\mathrm{H}$ \\
\hline 49 & $\mathrm{OCH}_{3}$ & $\mathrm{H}$ & $\mathrm{OH}$ & Pre & $\mathrm{OH}$ & $\mathrm{H}$ & $\mathrm{H}$ & $\mathrm{OH}$ & $\mathrm{H}$ & $\mathrm{H}$ \\
\hline
\end{tabular}

(b) 
<smiles>[R3]C1=C([R3])C(C)(C)Oc2c([R3])cc(/C=C/C(=O)c3c([R3])cc(O)c([R2])c3[R])cc21</smiles>

\begin{tabular}{cccccccc}
\hline & $\mathrm{R}_{1}$ & $\mathrm{R}_{2}$ & $\mathrm{R}_{3}$ & $\mathrm{R}_{4}$ & $\mathrm{R}_{5}$ & $\mathrm{R}_{6}$ & \\
\hline $\mathbf{5 0}$ & $\mathrm{H}$ & $\mathrm{H}$ & $\mathrm{OH}$ & $\mathrm{OH}$ & $\mathrm{H}$ & $\mathrm{H}$ & \\
\hline $\mathbf{5 1}$ & $\mathrm{H}$ & $\mathrm{H}$ & $\mathrm{OH}$ & $\mathrm{OH}$ & $\mathrm{H}$ & $\mathrm{OH}$ & $\Delta$ satd. \\
\hline $\mathbf{5 2}$ & $\mathrm{H}$ & $\mathrm{H}$ & $\mathrm{OH}$ & $\mathrm{OH}$ & $\mathrm{OH}$ & $\mathrm{OH}$ & $\Delta$ satd. \\
\hline $\mathbf{5 3}$ & $\mathrm{OH}$ & Pre & $\mathrm{H}$ & $\mathrm{H}$ & $\mathrm{H}$ & $\mathrm{H}$ & \\
\hline
\end{tabular}<smiles>[R5]C1=Cc2c(cc([R2])c(C(=O)/C=C/c3ccc([R5])c([R3])c3[R])c2[R])OC1(C)C</smiles>

\begin{tabular}{cccccccr}
\hline & $\mathrm{R}_{1}$ & $\mathrm{R}_{2}$ & $\mathrm{R}_{3}$ & $\mathrm{R}_{4}$ & $\mathrm{R}_{5}$ & $\mathrm{R}_{6}$ & \\
\hline $\mathbf{5 4}$ & $\mathrm{OH}$ & $\mathrm{OCH}_{3}$ & $\mathrm{H}$ & $\mathrm{H}$ & $\mathrm{OH}$ & $\mathrm{H}$ & \\
\hline $\mathbf{5 5}$ & $\mathrm{OH}$ & $\mathrm{OCH}_{3}$ & $\mathrm{H}$ & $\mathrm{H}$ & $\mathrm{OH}$ & $\mathrm{H}$ & $\Delta$ satd. \\
\hline $\mathbf{5 6}$ & $\mathrm{OH}$ & $\mathrm{H}$ & $\mathrm{H}$ & $\mathrm{H}$ & $\mathrm{OH}$ & $\mathrm{H}$ & \\
\hline $\mathbf{5 7}$ & $\mathrm{OH}$ & $\mathrm{H}$ & $\mathrm{H}$ & $\mathrm{H}$ & $\mathrm{OH}$ & $\mathrm{H}$ & $\Delta$ satd. \\
\hline $\mathbf{5 8}$ & $\mathrm{OCH}_{3}$ & $\mathrm{OH}$ & $\mathrm{OH}$ & $\mathrm{H}$ & $\mathrm{OH}$ & $\mathrm{Pre}$ & $\Delta$ satd. \\
\hline $\mathbf{5 9}$ & $\mathrm{OH}$ & $\mathrm{H}$ & $\mathrm{H}$ & $\mathrm{H}$ & $\mathrm{H}$ & $\mathrm{H}$ & \\
\hline $\mathbf{6 0}$ & $\mathrm{OH}$ & $\mathrm{H}$ & $\mathrm{H}$ & $\mathrm{OH}$ & $\mathrm{OCH}_{3}$ & $\mathrm{H}$ & \\
\hline $\mathbf{6 1}$ & $\mathrm{OH}$ & $\mathrm{H}$ & $\mathrm{H}$ & $\mathrm{H}$ & $\mathrm{OCH}_{3}$ & $\mathrm{H}$ & \\
\hline $\mathbf{6 2}$ & $\mathrm{OH}$ & $\mathrm{H}$ & $\mathrm{H}$ & $\mathrm{H}$ & $\mathrm{OH}^{2}$ & $\mathrm{H}$ & \\
\hline
\end{tabular}
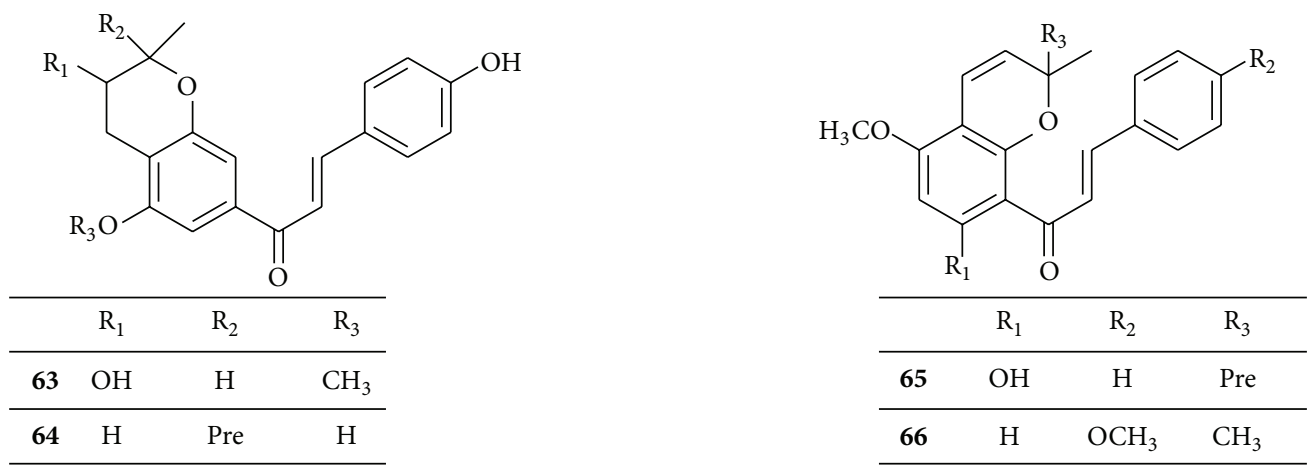<smiles>COc1cc(O)c2c(c1C(=O)/C=C/c1ccc(O)cc1)OC(C(C)(C)O)C2</smiles>

67<smiles>CC(C)=CCCC(C)(O)CCc1c(O)ccc(C(=O)/C=C/c2ccc(O)cc2)c1O</smiles>

69<smiles>CC(C)=CCC[C@]1(C)C=Cc2cc(C(=O)/C=C/c3ccc(O)cc3)c(O)cc2O1</smiles>

68<smiles>CC1(C)C=Cc2cc(/C=C/C(=O)c3ccc4c(c3O)C=CC(C)(C)O4)ccc2O1</smiles>

70

(c)

Figure 1: Continued. 


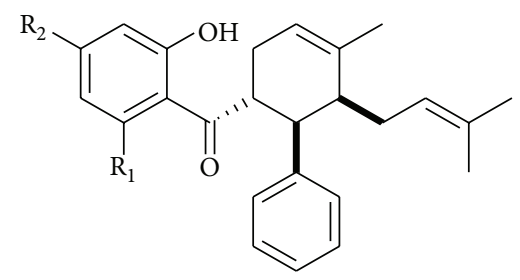

\begin{tabular}{ccc}
\hline & $\mathrm{R}_{1}$ & $\mathrm{R}_{2}$ \\
\hline 71 & $\mathrm{OH}$ & $\mathrm{OCH}_{3}$ \\
\hline 72 & $\mathrm{OCH}_{3}$ & $\mathrm{OH}$ \\
\hline 73 & $\mathrm{OH}$ & $\mathrm{OH}$ \\
\hline
\end{tabular}<smiles>CC(C)=CCc1c(O)ccc(C(=O)[C@H]2C(c3c(O)cc(-c4cc5ccc(O)cc5o4)cc3O)=C[C@]3(C)C[C@H]2c2ccc(O)cc2O3)c1O</smiles>

79<smiles></smiles><smiles>CC(C)=CCc1c(O)ccc(C(=O)[C@@H]2[C@@H](c3ccc(O)cc3O)C=C(C)C[C@H]2c2c(O)cc(-c3cc4ccc(O)cc4o3)cc2O)c1O</smiles><smiles>[R]c1ccc([C@H]2CC=C(C)[C@@H](CC=C(C)C)[C@H]2C(=O)c2c([R])cc([R2])cc2[R])cc1</smiles>

\begin{tabular}{ccccc}
\hline & $\mathrm{R}_{1}$ & $\mathrm{R}_{2}$ & $\mathrm{R}_{3}$ & $\mathrm{R}_{4}$ \\
\hline $\mathbf{7 4}$ & $\mathrm{OH}$ & $\mathrm{OCH}_{3}$ & $\mathrm{OH}$ & $\mathrm{H}$ \\
\hline $\mathbf{7 5}$ & $\mathrm{OCH}_{3}$ & $\mathrm{OH}$ & $\mathrm{OH}$ & $\mathrm{H}$ \\
\hline $\mathbf{7 6}$ & $\mathrm{OH}$ & $\mathrm{OH}$ & $\mathrm{OH}$ & $\mathrm{H}$ \\
\hline $\mathbf{7 7}$ & $\mathrm{OH}$ & $\mathrm{OH}$ & $\mathrm{OCH}_{3}$ & $\mathrm{OH}$ \\
\hline $\mathbf{7 8}$ & $\mathrm{OH}$ & $\mathrm{OCH}_{3}$ & $\mathrm{OCH}_{3}$ & $\mathrm{H}$ \\
\hline
\end{tabular}<smiles>CC(C)=CCc1c(O)ccc(C(=O)[C@@H]2[C@@H](c3ccc(O)cc3)C=C(C)C[C@H]2c2c(O)cc(-c3cc4ccc(O)cc4o3)cc2O)c1O</smiles>

80<smiles>C[C@@H]1C[C@H]2c3ccc(O)cc3O[C@]1(C)C=C(c1c(O)cc(-c3cc4ccc(O)cc4o3)cc1O)[C@@H]2C(=O)c1ccc(O)cc1O</smiles>

83<smiles></smiles>

85

(d) 
<smiles>CC1=C[C@H](c2cc3c(cc2O)OC(c2cc(O)cc(O)c2)C3)[C@H](C(=O)c2ccc(O)cc2O)[C@H](c2ccc(O)cc2O)C1</smiles>

86<smiles>CC(C)=CC[C@]12Oc3cc(O)c([C@@H]4C=C(C)C[C@H](c5ccc(O)cc5O)[C@H]4C(=O)c4ccc(O)cc4O)c(O)c3C(=O)[C@@]1(O)Oc1cc(O)ccc12</smiles><smiles>[R2]c1cc(O)ccc1/C=C/C(=O)c1ccc(O)c([C@@H]2C=C(C)C[C@H](c3ccc(O)cc3[R])[C@H]2C(=O)c2ccc(O)c(CC=C(C)C)c2O)c1O</smiles><smiles>COc1cc(O)c(Cc2ccccc2O)c(O)c1C(=O)/C=C/c1ccccc1</smiles>

96<smiles>Cc1cc2c3c(c1)-c1c(O)cc(-c4cc5ccc(O)cc5o4)cc1OC3(c1ccc(O)c3c1OC(C)(C)C=C3)Oc1cc(O)ccc1-2</smiles>

87<smiles>CC(C)=CC[C@]12Oc3cc(O)c([C@@H]4C=C(C)C[C@H](c5ccc(O)cc5O)[C@H]4C(=O)c4ccc(O)cc4O)c(O)c3C(=O)[C@@]1(O)Oc1cc(O)ccc12</smiles><smiles>[R]c1ccc(C(=O)/C=C/c2c(O)cc(OC)c(Cc3ccc(O)c(O)c3)c2OC)cc1O</smiles><smiles>O=C(/C=C/c1ccc(O)cc1O)c1cc(/C=C/C(=O)c2cc(-c3ccc(O)c(C(=O)/C=C/c4ccc(O)cc4)c3)c(O)cc2O)ccc1O</smiles>

(e)

Figure 1: Continued. 


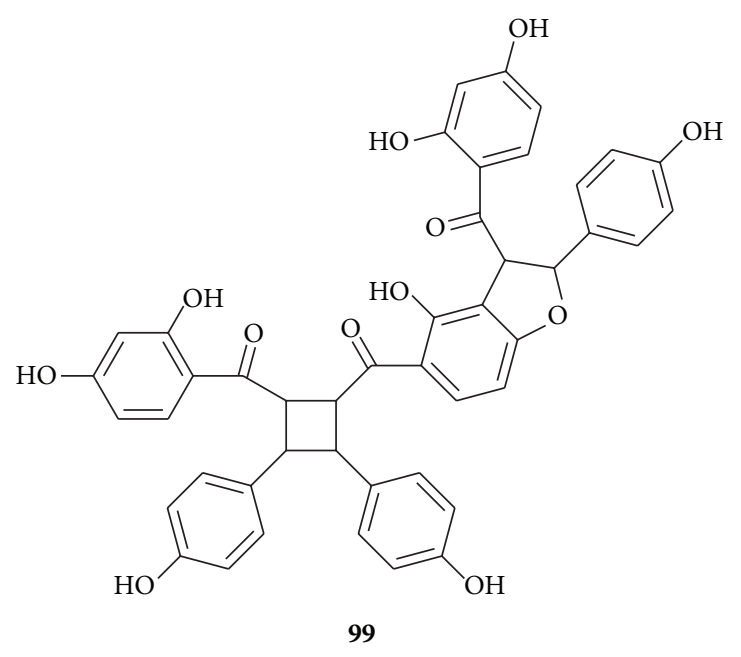

(f)

FiguRE 1: Structures of chalcones.

and B-ring, including hydroxyl and methoxy groups. These groups are usually located at C- $2^{\prime}, \mathrm{C}-4^{\prime}, \mathrm{C}-6^{\prime}$, and C- 4 and seldom appear at C-3', C-5', C-2, C-3, and C-6. In addition, $2 \mathrm{O}$-glycosylated chalcones $(\mathbf{1 8}, \mathbf{2 2})$ as well as $4 \mathrm{O}$-chalcone dimmers (23-26) are also included in this group.

2.2. Prenylated Chalcones. Prenylated chalcones (27-70) account for a significant proportion of chalcones. In structure, various isoprenoid-derived groups can be considered as substituents to the chalcone skeleton, such as prenyl, geranyl, furano, and pyranochalcones.

2.3. Diels-Alder Adducts. Chalcones (71-93) fall into the category of Diels-Alder adducts. Diels-Alder reaction is an organic chemical reaction (specifically, a cycloaddition) between a conjugated diene and a substituted alkene, commonly termed dienophile, to form a substituted cyclohexene system. Chalcones act as the dienophiles in Diels-Alder reactions, and the dienes that participate in the formation of the Diels-Alder adducts range from simple isoprene and monoterpene compounds to coumarins and other classes of flavonoids [3].

2.4. Others. In addition, antineoplastic chalcones above 3 groups were also reported recently, which include $3 \mathrm{C}$ benzylated chalcones (94-96), 2 dimmers $(\mathbf{9 7 , 9 8})$, and a trimer (99).

\section{Mechanisms of Antitumor Activity}

All chalcones illustrated in Figure 1 display antitumor activity through diverse mechanisms which can be generally organized into 10 categories in this section. Table 1 below provides a number of chalcones and specific tumor cell lines against which they show direct cytotoxicity, and Table 2 summarizes the inner mechanisms of antitumorous effect of each chalcone.
3.1. Cytotoxicity. In most cases, cell cytotoxicity was monitored using the MTT or MTS assay. Treatment of cells with chalcones can cause a decrease in cell viability, and then the cells undergo rapid necrosis or activate a programmed death (apoptosis). However, almost none of the investigations further reported the process and the way of cell death induced by chalcones in Table 1 .

In this table, chalcones exhibit cytotoxicity against a number of cell lines from a wide range of tumors, mainly including leukemia, hepatoma, breast cancer, colorectal cancer, stomach cancer, prostate cancer, and epidermoid carcinoma. Furthermore, the $\mathrm{IC}_{50}$ values of the majority of compounds were below $50 \mu \mathrm{M}$, especially that of chalcone 7 reaching nanomolar concentration, indicating the significant cytotoxicity of chalcones.

In spite of the strong activity of chalcones, they do not always show the ideal selectivity between normal cells and tumorous cells. Also, the underlying mechanisms causing cell death remain to be elucidated in detail.

3.2. Apoptosis. Apoptosis is the process of programmed cell death that may occur in multicellular organisms. It involved two central pathways in general. One involves the stimulation of death receptors (DRs) of the tumor necrosis factor (TNF) receptor superfamily, and the other is the mitochondrial pathway initiated by Bcl-2 family proteins [36].

3.2.1. Death Receptor-Mediated Pathway. Death receptors are the members of TNF receptor superfamily, and all contain an intracellular death domain that serves to recruit adapter proteins such as TRADD and FADD and the initiator caspase-8. Caspases are cysteine proteases that cleave proteins at aspartic acid residues contained within a tetrapeptide recognition motif. There are two types of apoptotic caspases, namely, initiator caspases and effector caspases. Initiator caspases (caspase-2, -8, -9, -10) mediate the transduction of death signal and promote the formation of death-inducing signaling 
TABLE 1: Chalcones and the corresponding cell lines inhibited by them.

\begin{tabular}{|c|c|c|}
\hline Chalcones & Cell lines & Reference \\
\hline Butein (1) & HSC-2, HSC-3, HSG, HL-60 & {$[4]$} \\
\hline Flavokawain B (2) & T24, KB, HCT116 & {$[5]$} \\
\hline Flavokawain C (17) & T24, PANC-1 & {$[6,7]$} \\
\hline Pinostrobin chalcone (3) & KB, MCF7, Caski, MRC5 & [5] \\
\hline $\begin{array}{l}2^{\prime}, 4^{\prime} \text {-dihydroxy-3,4-dimethoxychalcone (4), } \\
2^{\prime}, 4^{\prime} \text {-dihydroxy-2,3-dimethoxychalcone (5), } \\
2^{\prime}, 4^{\prime} \text {-dihydroxy-4-methoxychalcone }(\mathbf{6})\end{array}$ & HL-60, SMMC-7721 & {$[8]$} \\
\hline $2^{\prime}, 4^{\prime}$-dihydroxy-3', $5^{\prime}$-dimethyl- $6^{\prime}$-methoxychalcone (7) & $\begin{array}{l}\text { SMMC-7721, 8898, HeLa, } \\
\text { SPC-A-1, 95-D, GBC-SD, MCF-7, } \\
\text { SKBR-3, SW-480 }\end{array}$ & {$[9,10]$} \\
\hline Stercurensin $(\mathbf{8})$ & SW-480 & {$[11]$} \\
\hline Cardamonin (9) & SW-480, PANC-1 & {$[11]$} \\
\hline $2^{\prime}, 4^{\prime}$-dihydroxychalcone $(\mathbf{1 0})$ & $\begin{array}{l}\text { 26-L5, B16-BL6, LLC, A549, } \\
\text { HeLa, HT-1080 }\end{array}$ & {$[12]$} \\
\hline $4,4^{\prime}$-dihydroxy-2' -methoxychalcone (11) & $\begin{array}{l}\text { 26-L5, B16-BL6, LLC, A549, } \\
\text { HeLa, HT-1080, SH-SY5Y }\end{array}$ & {$[12,13]$} \\
\hline Isoliquiritigenin (12) & $\begin{array}{l}\text { 26-L5, B16-BL6, LLC, A549, } \\
\text { HeLa, HT-1080 }\end{array}$ & {$[12,14]$} \\
\hline  & MCF-7/ADR, BEL-7402/5-FU & {$[15]$} \\
\hline $3^{\prime}$-formyl-2', $4^{\prime}$-dihydroxy- $6^{\prime}$-methoxychalcone (20) & KB, MCF-7 & {$[16]$} \\
\hline Abyssinone A (50), B (51), C (52), D (27) & $\mathrm{Caco} 2$ & {$[17]$} \\
\hline $\begin{array}{l}5^{\prime \prime}-\left(2^{\prime \prime \prime} \text {-hydroxyisopropyl- }\right) \text {-dihydrofurano- }\left[2^{\prime \prime}, 3^{\prime \prime}-\mathrm{B}\right]-4,4^{\prime} \text {-dihydroxy- } 6^{\prime}- \\
\text { methoxychalcone } \\
(67)\end{array}$ & BGC-823 & {$[18]$} \\
\hline $\begin{array}{l}\text { Flavokawin (13), } \\
3^{\prime} \text {-geranylchalconaringenin (29), } \\
5^{\prime} \text {-prenylxanthohumol (30), } \\
\text { xanthohumol H (31), xanthogalenol (33), } \\
\text { 4-methylxanthohumol (34), } \\
\text { xanthohumol C (53), } \\
1^{\prime \prime}, 2^{\prime \prime} \text {-dihydroxanthohumol C (55) }\end{array}$ & HeLa & {$[19]$} \\
\hline Desmethylxanthohumol (32) & HeLa, DU145, PC-3 & {$[20,21]$} \\
\hline Licochalcone A (35), C (36), E (37) & HT-1080 & {$[14]$} \\
\hline $2^{\prime}, 4^{\prime}, 2,4$-tetrahydroxy- $3^{\prime}$-prenyl-6 $6^{\prime}$-methoxychalcone (38) & HL-60, L1210, U937 & {$[22]$} \\
\hline Cyclokuraridin (58) & $\mathrm{KB}$ & {$[23]$} \\
\hline 3-hydroxy-4-methoxylonchocarpin (60) & $\begin{array}{l}\text { A2780, B16, K562, LL/2, 7860, } \\
\text { HeLa }\end{array}$ & {$[24]$} \\
\hline 4-methoxylonchocarpin (61) & $\begin{array}{l}\text { HeLa, K562, LL/2, 7860, A2780, } \\
\text { B16 }\end{array}$ & {$[24]$} \\
\hline Isobavachromene (62) & $\begin{array}{l}\text { 7860, A549, A2780, B16, HeLa, } \\
\text { K562, LL2 }\end{array}$ & {$[24]$} \\
\hline Millepachine (66) & HepG2, C26, LL2, B16 & {$[25]$} \\
\hline $5^{\prime}$-geranyl-2', $4^{\prime}, 4$-trihydroxychalcone (39) & $\begin{array}{l}\text { SW 872, HT-29, Hep3B, PLC5, } \\
\text { Huh7, HepG2, COLO205 }\end{array}$ & {$[26]$} \\
\hline Isocordoin (40) & P388 & {$[27]$} \\
\hline $\begin{array}{l}\text { Derricin (41), } \\
\text { lonchocarpin (59) }\end{array}$ & CEM & {$[28]$} \\
\hline Isobavachalcone (42) & HT-1080, MCF-7, MCF-7/ADR & [29] \\
\hline 4-hydroxyderricin (47) & KATO III & {$[30]$} \\
\hline
\end{tabular}


TABle 1: Continued.

\begin{tabular}{|c|c|c|}
\hline Chalcones & Cell lines & Reference \\
\hline Xanthoangelol (44) & $\begin{array}{l}\text { SW 872, HT-29, COLO205, } \\
\text { Hep3B, PLC5, Huh7, HepG2, } \\
\text { KATO III }\end{array}$ & {$[26,30]$} \\
\hline Isolespeol (68) & $\begin{array}{l}\text { HT-29, COLO205, Hep3B, PLC5, } \\
\text { Huh7 }\end{array}$ & [26] \\
\hline $\begin{array}{l}2^{\prime}, 4^{\prime} \text {-dihydroxy- } 3^{\prime}-\left(1^{\prime \prime} \text {-geranyl)- } 6^{\prime} \text {-methoxychalcone }(\mathbf{2 8}),(-) \text {-nicolaioidesin B (71), }\right. \\
( \pm) \text {-isopanduratin A1 (72), } \\
\left(1^{\prime} \mathrm{R}, 2^{\prime} S, 6^{\prime} \mathrm{R}\right)-2 \text {-hydroxyisopanduratin A (73), } \\
\text { panduratin A (74), (-)-isopanduratin A2 (75), } \\
(-) \text {-hydroxypanduratin A (76), } \\
( \pm) \text {-panduratin C (77), } \\
( \pm) \text {-6-methoxypanduratin A (78), }\end{array}$ & PANC-1 & {$[7]$} \\
\hline Australisine A (85) & HCT-8, A2780 & [31] \\
\hline $\begin{array}{l}\text { Australisine B (79), mulberrofurans E (80), F (81), mongolicin C (83), chalcomoracin } \\
\text { (84) }\end{array}$ & $\begin{array}{l}\text { A549, Bel7402, BGC-823, } \\
\text { HCT-8, A2780 }\end{array}$ & {$[31]$} \\
\hline Mulberrofuran G (82) & A549, BGC-823, HCT-8, A2780 & {$[31]$} \\
\hline Australisine C (86) & A2780 & {$[31]$} \\
\hline Yunanensin A (87) & $\begin{array}{l}\text { A549, Bel7402, BGC-823, } \\
\text { HCT-8, A2780 }\end{array}$ & {$[32]$} \\
\hline Japonicone A (94) & $\begin{array}{l}\text { HeLa, Bel7402, MCF-7/ADR, } \\
\text { Bel7402/5-FU }\end{array}$ & {$[33]$} \\
\hline 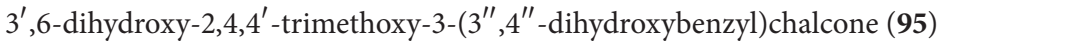 & MCF-7/ADR, BEL-7402/5-FU & [15] \\
\hline $2^{\prime}, 4^{\prime}$-dihydroxy-3'-(2-hydroxybenzyl)-6' -methoxychalcone (96) & $\mathrm{KB}, \mathrm{BC}$ & [34] \\
\hline Rhuschalcones I (23), II (24), III (25), V (97), VI (98) & HT-29, HCT-116 & {$[35]$} \\
\hline Rhuschalcone IV (26) & $\begin{array}{l}\text { HT-29, HCT-116, SK-MEL-5, } \\
\text { SK-MEL-28, UACC-62 }\end{array}$ & {$[35]$} \\
\hline Xanthohumol (49) & $\begin{array}{l}\text { DU145, PC-3, HeLa, } \\
\text { MCF-7/ADR, HT-1080 }\end{array}$ & {$[19-21,29]$} \\
\hline
\end{tabular}

complex. Effector caspase (caspase-3, -6, -7) in turn cleave key cellular proteins or activate other degradation enzymes to execute the apoptosis [37]. Cleavage of the DNA repairassociated enzyme poly (ADP-ribose) polymerase (PARP) is accepted as a prominent marker of apoptosis [38].

Chowdhury et al. investigated 11 compounds for their cytotoxicity and apoptosis-inducing activity in four human tumor cell lines, HSC-2, HSC-3, HSG and HL-60. Among them, isoliquiritigenin exhibited higher cytotoxicity against tumor cells than normal cells with a tumor-specific index of 4.0. It induced internucleosomal DNA fragmentation and activation of caspase-3, -8 and -9 dose-dependently [4]. Xanthoangelol exhibited concentration-dependent cytotoxicity against human neuroblastoma IMR-32 and leukemia Jurkat cells through activation of caspase-3 [39]. Similarly, millepachine activated caspase- 3 in HeLa-C3 cells within $36 \mathrm{~h}$ at the concentration of $5 \mu \mathrm{M}$ [25]. In addition, panduratin A, isolated from an extract of Kaempferia pandurata, was a strong inhibitor of cyclooxygenase-2 (COX-2) in RAW264.7 cells. This property was also revealed against HT-29 colon cancer cells because its treatment with panduratin A led to cleavage of PARP along with the decrease of procaspase- 3 [40].

TNF-related apoptosis-inducing ligand (TRAIL), a member of TNF superfamily, selectively induces apoptosis in cancer cells with no toxicity to normal tissues [41]. However, more than $50 \%$ of tumor cells are resistant to TRAIL at different and/or multiple levels in the signaling pathway. Combined treatment with other therapeutic agents is a potential way to circumvent resistance and resensitize tumors. Compounds of natural origin play a specific role in this activity [42]. For example, butein exhibited significant synergism with TRAIL and sensitized TRAIL-resistant human leukemia U937 cells to apoptosis. It also increased caspase-3 activity and expression of DR5 [43]. In addition, butein, isobavachalcone, xanthohumol, licochalcone A and $2^{\prime}, 6^{\prime}$-dihydroxy- $4^{\prime}$ methoxychalcone can markedly enhance TRAIL-mediated apoptosis and cytotoxicity in prostate cancer LNCaP cells. The combination of butein and TRAIL increased the percentage of cell death by $36.82-81.97 \%$ compared to TRAIL or butein alone. And the percentage of that was $24.47 \%-$ $85.90 \%$ for isobavachalcone, $26.22 \%-93.20 \%$ for xanthohumol, 25.36-89.32\% for licochalcone A, and 24.65\%-67.59\% for $2^{\prime}, 6^{\prime}$-dihydroxy-4'-methoxychalcone $[44,45]$. Also, the augment of TRAIL-induced apoptosis by isobavachalcone, xanthohumol and licochalcone A was verified in HeLa cells by increased expression of DR5 [46].

Activity-guided fractionations of the extract of Catimbium speciosum afforded six compounds with DR5 inducing activity. The combination of cardamonin, the most active 
TABLE 2: Chalcones and their mechanisms.

\begin{tabular}{|c|c|c|}
\hline Chalcones & Mechanisms & Reference \\
\hline Cardamonin (9) & \multirow{8}{*}{ Induction of apoptosis } & {$[47]$} \\
\hline Flavokawain A (16) & & {$[6]$} \\
\hline Flavokawain B (2) & & {$[50-52]$} \\
\hline Ashitaba chalcone (43) & & {$[53]$} \\
\hline Isolespeol (68) & & {$[26]$} \\
\hline Boesenbergin A (65) & & {$[57]$} \\
\hline Millepachine (66) & & {$[25]$} \\
\hline $2^{\prime}, 6^{\prime}$-dihydroxy-4'-methoxychalcone (14) & & {$[45]$} \\
\hline \multirow{2}{*}{$2^{\prime}, 4^{\prime}$-dihydroxy-3', $5^{\prime}$-dimethyl- $6^{\prime}$-methoxychalcone (7) } & Induction of apoptosis & {$[54]$} \\
\hline & Antiangiogenesis & {$[120]$} \\
\hline \multirow{8}{*}{ Isoliquiritigenin (12) } & Induction of apoptosis & {$[4,48,55]$} \\
\hline & Induction of apoptosis under hypoxia & {$[64]$} \\
\hline & Chemoprevention & [78-81] \\
\hline & Cell signal transduction & {$[93]$} \\
\hline & Antimetastasis & {$[109]$} \\
\hline & Regulation of cell cycle & {$[112-116]$} \\
\hline & Redifferentiation & {$[126]$} \\
\hline & Supplement for cisplatin chemotherapy & {$[127]$} \\
\hline \multirow{3}{*}{ Xanthoangelol (44) } & Induction of apoptosis & {$[39,56]$} \\
\hline & Chemoprevention & {$[85]$} \\
\hline & Antimetastasis & {$[107]$} \\
\hline \multirow{3}{*}{ Isobavachalcone (42) } & Induction of apoptosis & {$[44,58]$} \\
\hline & Chemoprevention & {$[85,86]$} \\
\hline & Cell signal transduction & {$[94]$} \\
\hline \multirow{8}{*}{ Xanthohumol (49) } & Antimetastasis & {$[106]$} \\
\hline & Induction of apoptosis & {$[44,59]$} \\
\hline & Induction of apoptosis under hypoxia & {$[65]$} \\
\hline & $\mathrm{NF}-\kappa \mathrm{B}$ pathway & {$[70-73]$} \\
\hline & Chemoprevention & {$[90,92]$} \\
\hline & Cell signal transduction & {$[98]$} \\
\hline & Antiinvasion & [101-104] \\
\hline & Antiangiogenesis & [121-125] \\
\hline \multirow{3}{*}{ Panduratin A (74) } & Induction of apoptosis & {$[40]$} \\
\hline & NF- $\kappa$ B pathway & {$[74]$} \\
\hline & Regulation of cell cycle & {$[111]$} \\
\hline \multirow{5}{*}{ Butein (1) } & Induction of apoptosis & {$[43,44]$} \\
\hline & NF- $\kappa$ B pathway & {$[69]$} \\
\hline & Chemoprevention & {$[77]$} \\
\hline & Cell signal transduction & {$[95]$} \\
\hline & Fibroblasts & {$[128]$} \\
\hline \multirow{2}{*}{ Licochalcone A (35) } & Induction of apoptosis & {$[44]$} \\
\hline & Regulation of cell cycle & {$[119]$} \\
\hline $\begin{array}{l}\text { Sanggenon O (88), C (89), kuwanon J (90), Q (91), R } \\
(\mathbf{9 2}), \mathrm{V}(\mathbf{9 3})\end{array}$ & Induction of apoptosis under hypoxia & {$[63]$} \\
\hline Naringenin chalcone (19), isosalipurposide (18) & Cell signal transduction & {$[96]$} \\
\hline
\end{tabular}


TABLE 2: Continued.

\begin{tabular}{|c|c|c|}
\hline Chalcones & Mechanisms & Reference \\
\hline Xanthoangelol F (48) & \multirow{3}{*}{ Chemoprevention } & {$[85]$} \\
\hline Isoliquiritin apioside (22) & & {$[91]$} \\
\hline Xanthoangelol I (64), J (49), & & {$[86]$} \\
\hline \multirow{2}{*}{ Xanthoangelol H (63) } & Induction of apoptosis & {$[58]$} \\
\hline & Chemoprevention & [85] \\
\hline 1,2-dihydroparatocarpin A (70) & Chemoprevention & {$[83]$} \\
\hline \multirow{2}{*}{ 4-hydroxyderricin (47) } & Chemoprevention & {$[85]$} \\
\hline & Antimetastasis & {$[108]$} \\
\hline $2^{\prime}$-hydroxy-2,3,4',6 -tetramethoxychalcone (21) & Regulation of cell cycle & {$[117,118]$} \\
\hline \multirow{2}{*}{ Isocordoin (40) } & Cell signal transduction & {$[97]$} \\
\hline & Regulation of cell cycle & {$[27]$} \\
\hline Kanzonol C (45), 4-hydroxylonchocarpin (56) & \multirow{2}{*}{ Antimetastasis } & [105] \\
\hline Paratocarpin C (53), stipulin (46), dorsmannin A (57) & & [106] \\
\hline Pauferrol A (99) & DNA topoisomerase II & [129] \\
\hline
\end{tabular}

compound, and TRAIL synergistically enhanced TRAILinduced apoptosis of TRAIL-resistant human colon cancer (DLD1/TR) and human gastric adenocarcinoma cells. The mechanism of the apoptosis induction in DLD1/TR cells was associated with the upregulation of DR4 and DR5 due to activation of caspase-8, 9, and 3. Moreover, upregulation of DR5 by cardamonin was accompanied with the induction of CCAAT/enhancer-binding protein-homologous protein (CHOP) [47]. Similarly, the combination of suboptimal concentration of isoliquiritigenin and TRAIL drastically enhanced apoptosis in colon cancer HT-29 cells compared with the single treatment of isoliquiritigenin. Isoliquiritigenin upregulated the level of DR5 and the combination of two agents induced apoptosis synergistically through activation of caspase- $8,-10,-9$, and -3 [48].

3.2.2. Mitochondrial-Mediated Pathway. Mitochondrial pathway is regulated by Bcl-2 family of proteins. These proteins can dominate the permeability of mitochondrial outer membrane, and they are either proapoptotic (Bax, $\mathrm{Bak}$, and Bad) or antiapoptotic (Bcl-2, Bcl-xL, and Bcl$\mathrm{W})$. The changes of mitochondrial membrane induced by proapoptotic factors result in cytochrome $c$ release and the production of reactive oxygen species (ROS), while antiapoptotic members reside in the outer mitochondrial membrane and counter these effects. Death receptor and mitochondrial-mediated pathways are intimately connected. Cytochrome c released into cytoplasm is associated with Apaf-1 and then activates procaspase-9 to assemble the apoptosome [36, 49]. Thus, downstream caspase cascade is activated.

The Kava extract and flavokawains A, B, and C showed strong antiproliferative and apoptotic effects on human bladder cancer cells characterized as low grade or high grade. Flavokawain A induced a loss of mitochondrial membrane potential and release of cytochrome $\mathrm{c}$ in an invasive bladder cancer cell line T24, which were associated with an increase in Bax/Bcl-xL ratio and Bax confirmation change in T24 cells.
Furthermore, it was observed that Bax protein was, at least in part, required for the apoptotic effect of flavokawain A on primary mouse embryo fibroblasts, and Bax inhibitory peptide P5 attenuated the antiproliferative effect of flavokawain A on T24 cells. In addition, flavokawain A downregulated the expression of X-linked inhibitor of apoptosis and survivin and remarkably inhibited growth of bladder tumor cells in a nude mice model and in soft agar [6].

Also, flavokawain B exerted the apoptotic action on HCT116 cells through ROS generation and GADD 153 upregulation, which led to mitochondria-dependent apoptosis. The upregulation of GADD 153 was linked with mitochondrial dysfunction and altered expression of Bcl-2 family members. Besides, flavokawain B was able to induce G2/M accumulation as well as autophagy [50].

Tang et al. compared the inhibitory activity of flavokawain $\mathrm{B}$ on the growth of androgen receptor- (AR-) negative, hormone-refractory prostate cancer cell lines DU145 and PC3 with the AR-positive, hormone-sensitive cell lines LAPC4 and LNCap. This compound was 4- to 12-folds as effective on the former cell lines as the latter ones, with minimal effects on normal prostatic epithelial and stromal cells. It induced apoptosis through upregulation DR5, Bim and Puma expression and downregulation of XIAP, and surviving expression, which resulted in activation of the Bax-initiated mitochondria pathway. It was observed that significant increase of Bim expression played a critical role in flavokawain B-mediated apoptosis and flavokawain B exerted a synergistic apoptotic effect when combined with TRAIL. Moreover, flavokawain $\mathrm{B}$ was demonstrated to inhibit tumor growth and increase Bim expression in the mice bearing DU145 xenograft tumors [51]. Flavokawain B was also effective in human squamous carcinoma in vitro and in vivo. Both death receptor and mitochondrial pathways were involved, which was evidenced by the activation of caspase- $9,-3$, and -8 and cleavage of PARP and Bid, as well as changes of Bcl-2 and Bax levels. It induced $\mathrm{G} 2 / \mathrm{M}$ phase block via reduction of cyclin $\mathrm{A}$, cyclin B1, Cdc2, and Cdc25C and augmentation of p21/WAF1, 
Weel, and p53. Moreover, tumor metastasis-related proteins, such as matrix metalloproteinase-9 (MMP-9) and urokinase plasminogen activator (u-PA), were decreased and the endogenous inhibitors tissue inhibitor of MMP-1 and plasminogen activator inhibitor-1 (PAI-1) were increased. In addition, the in vivo effect on tumor was shown in $\mathrm{KB}$ cellderived tumor xenografts in nude mice and the induction of DNA fragmentation was observed [52].

Recently, Meng et al. reported that Ashitaba chalcone, a prenylated chalcone isolated from Ashitaba, could induce expressions of caspase- 3 and Bax protein and inhibit proliferation of mouse hepatocarcinoma cells [53].

$2^{\prime}, 4^{\prime}$-dihydroxy-3',5'-dimethyl-6' -methoxychalcone exhibited cytotoxicity against human chronic leukemia K562 cells in vitro with an $\mathrm{IC}_{50}$ value of $14.2 \mu \mathrm{M}$ and was found to be able to induce apoptosis of K562. Further analysis on the mechanism revealed that this compound was able to downregulate the level of Bcl-2 protein without any effects on the expression of Bax protein [54].

Isoliquiritigenin led to dose-dependent decrease of the viable cell numbers and induction of apoptosis in DU145 and MAT-LyLu rat prostate cancer cells. It upregulated the levels of membrane-bound FasL, Fas, cleaved caspase-8, truncated Bid, Bax, and Bad in DU145 cells. Also, it increased the percentage of cells with depolarized mitochondrial membranes in a concentration-dependent manner. Additionally, isoliquiritigenin induced the release of cytochrome $c$ and Smac/Diablo from the mitochondria into the cytoplasm and upregulated the levels of cleaved caspase-9, -7 , and -3 and PARP [55].

Subsequently, Motani et al. conducted another study to clarify the mechanism of xanthoangelol apoptotic action in neuroblastoma cells. It increased ROS and induced the release of cytochrome $c$ and activation of caspase- 9 in IMR32 cells. DJ-1 protein was involved in the apoptosis and was downregulated by xanthoangelol, which resulted in the loss of antioxidant function and promotion of apoptosis. Moreover, xanthoangelol exhibited cytotoxic effect on both drug-resistant LA-N-1 and NB-39 cells and drug-sensitive IMR-32 and SK-N-SH cells [56].

Boesenbergin A induced apoptosis via the regulation of the expression of Bcl-2 and Bax and significantly increased caspase-3, -7, -9, and -8. Moreover, it induced MMP disruption and increased ROS formation. In addition, the HSP 70 protein, which is well known to prevent protein aggregation caused by the oxidative stress in tumor cells, decreased concomitantly [57].

Isolespeol exhibited the strongest activity in human liposarcoma cells SW 872 with an $\mathrm{IC}_{50}$ value of $3.8 \mu \mathrm{M}$. It caused the loss of mitochondrial membrane potential and increased expression of Fas, FasL, and p53 and led to the regulation of $\mathrm{Bcl}-2$ family members and subsequent activation of caspase- 3 and -9 followed by cleavage of PARP [26].

Also, isobavachalcone and xanthoangelol $\mathrm{H}$ demonstrated the cytotoxicity against neuroblastoma cell lines IMR32 and NB-39 with no effects on normal cells. Isobavachalcone induced apoptosis which was evidenced by the significantly reduction of procaspase- 3 and -9 and subsequently increase of cleaved caspase- 3 and -9 levels in both neuroblastoma cell lines. Moreover, Bax was induced markedly by isobavachalcone as well [58].

In addition, xanthohumol significantly reduced proliferation of HCT116-derived colon cancer cell line 40-16. Further experiments clarified that xanthohumol induced apoptosis through downregulation of $\mathrm{Bcl}-2$ and activation of the death receptor pathway, indicated by activation of caspase- $3,-7,-8$, and -9 [59].

3.3. Apoptosis under Hypoxia. Tumor hypoxia is the situation where tumor cells have been deprived of oxygen. As a tumor grows, it rapidly outgrows its blood supply, leaving portions of the tumor with regions where the oxygen concentration is significantly lower than in healthy tissues. In case of solid tumors, most tumor cells exist in chronic hypoxia, little nutrients, and low $\mathrm{pH}$ condition. Many genes, related to metabolism of energy, apoptosis and angiogenesis, are regulated in these hypoxic cells [60]. Hypoxia inducible factor (HIF) is recognized as a key protein in hypoxic signaling transduction. HIF-1 is thought to play important roles in tumor proliferation, angiogenesis, and metastasis [61, 62].

Six Diels-Alder adducts including sanggenons $\mathrm{O}$ and $\mathrm{C}$ from Mori Cortex Radicis, kuwanons J, Q, R, and V from Morus bombycis, as well as isoliquiritigenin, were found to strongly inhibit HIF-1 $[63,64]$. Sanggenon O and kuwanon J also exhibited dose-dependent inhibition of hypoxia-induced HIF- $1 \alpha$ accumulation and inhibited vascular endothelial growth factor (VEGF) secretion in Hep3B cells [63]. Xanthohumol could reverse the hypoxia-induced upregulation of the triglyceride synthesis and cancel the appearance of lipid droplets in the cytoplasm completely. It suppressed the proliferation of HT-1080 human fibrosarcoma in hypoxic condition as well as the motility enhanced by hypoxia, which demonstrated the potent and specific activities of xanthohumol against cancerous cells in hypoxic condition [65].

3.4. NF- $\kappa B$ Pathway. NF- $\kappa \mathrm{B}$, short for nuclear factor kappalight-chain enhancer of activated $B$ cells, is another transcription factor which is emerging as a potential target. While in an inactivated form, NF- $\kappa \mathrm{B}$ resides in the cytoplasm complexed with the inhibitory protein $\mathrm{I} \kappa \mathrm{Bs}$. I $\kappa \mathrm{B}$ kinases (IKK) phosphorylate $\mathrm{I} \kappa \mathrm{B}$ proteins, which results in proteasomeassisted degradation of $\mathrm{I} \kappa \mathrm{B}$ and then the translocation of NF$\kappa \mathrm{B}$ into nucleus. The activated NF- $\kappa \mathrm{B}$ binds itself to specific sequence of gene, leading to a change of cell function $[66,67]$. In many kinds of tumor cells, NF- $\kappa \mathrm{B}$ is constitutively active, and it keeps the cell proliferating and protects cells from the proapoptotic action of antitumor agents [68]. Accordingly, blocking NF- $\kappa \mathrm{B}$ is considered as an important strategy in cancer therapy.

Butein inhibited TNF-induced NF- $\kappa \mathrm{B}$ activation in a dose- and time-dependent manner, suppressed the NF- $\kappa \mathrm{B}$ activation induced by various carcinogens and inflammatory agents, and inhibited the $\mathrm{NF}-\kappa \mathrm{B}$ reporter activity induced by TNFR1, TRADD, TRAF2, NIK, TAK1/TAB1, and IKK$\beta$. It directly inhibited IKK activation, which subsequently 
blocked $\mathrm{I} \kappa \mathrm{B} \alpha$ phosphorylation and degradation. The direct inactivation of IKK by butein involved cysteine residue 179 , which was associated with the suppression of phosphorylation and the nuclear translocation of p65. Butein also suppressed the expression of $\mathrm{NF}-\kappa \mathrm{B}$ regulated gene products involved in antiapoptosis (IAP2, Bcl-2, and $\mathrm{Bcl}-\mathrm{xL}$ ), proliferation (cyclin D1 and c-Myc) and invasion (COX-2 and MMP-9), which resulted in potentiation of apoptosis induced by TNF as well as chemotherapeutic agents and suppression of cellular invasion [69].

Xanthohumol could enhance TNF-induced apoptosis in leukemia and myeloma cells, which was linked with downregulation of NF- $\kappa$ B survival. Xanthohumol abrogated both constitutive and inducible NF- $\kappa \mathrm{B}$ activation, inhibited phosphorylation and degradation of $\mathrm{I} \kappa \mathrm{B} \alpha$, and suppressed p65 nuclear translocation and NF- $\kappa \mathrm{B}$-dependent reporter gene transcription. Inhibition of TNF-induced IKK activation and binding of p65 to DNA by xanthohumol could be reversed by a reducing agent, which indicated the role of cysteine residue. Thus, xanthohumol potentiated apoptosis in leukemia cell through modification of cysteine residues in IKK and $\mathrm{p} 65$ and thereby inhibited NF- $\kappa$ B activation pathway [70]. Also, xanthohumol induced significant apoptosis of two hepatocellular carcinoma cell lines (HepG2 and Huh7) at $25 \mu \mathrm{M}$ and showed antiproliferation and antimigration activities, inhibited TNF-induced NF- $\kappa$ B activity, and interleukin8 at even lower concentrations. Nevertheless, the viability of primary human hepatocytes was not affected by the concentration of xanthohumol as high as $100 \mu \mathrm{M}$ [71].

Moreover, xanthohumol exhibited strong growthinhibitory and apoptosis-inducing activity in both hormonesensitive and refractory human prostate cancer cell lines. It induced apoptosis through enhancement of binding of V-FITC to cancer cells, cleavage of PARP-1, activation of procaspase-3, -8 , and -9 , mitochondrial depolarization, and release of cytochrome $c$. The induction of apoptosis was associated with inhibition of Akt (protein kinase B), NF- $\kappa \mathrm{B}$ and mTOR prosurvival signaling proteins, and $\mathrm{NK}-\kappa \mathrm{B}$ mediated Bcl-2 pathway [72]. Xanthohumol also exhibited its potential through activation of Bax, $\mathrm{p} 53$, and downregulation of NF- $\kappa \mathrm{B}$ activation in human benign prostate hyperplasia epithelial BPH-1 cells [73]. In addition, panduratin A was found to be an inhibitor of NF- $\kappa \mathrm{B}$ translocation activated by TNF, and it caused growth inhibition in A549 cells and G2/M phase block [74].

3.5. Chemoprevention. Estrogen exposure is considered to be closely linked to the mutation and proliferation of breast cancer. Aromatase is the enzyme that synthesizes estrogen and its inhibitors can either block the production of estrogen or the action of estrogen on receptors $[75,76]$. Butein can modulate estrogen metabolism and inhibit proliferation of breast cancer cells as an inhibitor of aromatase with an $\mathrm{IC}_{50}$ value of $3.75 \mu \mathrm{M}$. Further enzyme kinetic study revealed that butein acted on aromatase with a mixed type of inhibition and the $K_{i}$ value was $0.32 \mu \mathrm{M}$. The cell number increased by $10 \mathrm{nM}$-testosterone treatment was remarkably reduced by $5 \mu \mathrm{M}$ butein, and the administration of flutamide could not reverse the effect [77].
Isoliquiritigenin exhibited either antitumorigenic activity or estrogen receptor $\alpha$-(ER $\alpha$-) dependent growth promoting effects on breast cancer cells. Maggiolini et al. studied this paradox in detail using the hormone-sensitive MCF-7 breast cancer cells and the steroid-independent HeLa cells as model systems. It could transactivate the endogenous $\operatorname{ER} \alpha$ due to the downregulation of ER $\alpha$ protein levels and upregulation of pS2 mRNA. This compound was also proved to be an estrogenic agonist of $\mathrm{ER} \alpha$ and $\mathrm{ER} \beta$. As a biological counterpart, low and intermediate concentrations of isoliquiritigenin stimulated the proliferation of MCF-7 cells, whereas its high levels became cytotoxic even in steroid-receptor negative HeLa cells [78].

Azoxymethane- (AOM-) induced aberrant crypt focus (ACF) formation model in mice is often used to evaluate the potency of chemopreventive agents against colon cancer. Administration of isoliquiritigenin in drinking water significantly suppressed AOM-induced ACF formation, with an inhibitory ratio of $37.3 \%$. Isoliquiritigenin administrated along with diet also significantly inhibited AOM-induced colon carcinogenesis [79]. Chin et al. demonstrated that isoliquiritigenin prevented colon and lung tumors induced by 1,2-dimethylhydrazine in mice when administered at a dose of $300 \mathrm{mg} / \mathrm{kg}$ [80]. It significantly decreased $\mathrm{PGE}_{2}$ production through downregulation of COX-2 expression and suppressed NO production by decreasing iNOS protein expression in RAW264.7 mouse macrophage cells. Isoliquiritigenininduced growth inhibition and apoptosis in mouse and human colon carcinoma cells might be due to the inhibition of both $\mathrm{PGE}_{2}$ and $\mathrm{NO}$ production. Moreover, it was reported that in vivo administration of isoliquiritigenin inhibited preneoplastic ACF induction in the male F344 rat colon [81]. Also, isoliquiritigenin was proved to induce phase 2 enzymes, including quinone reductase $(\mathrm{QR})$ and gluthatione S-transferase in the rat liver tissue [82]. And it exhibited significant peroxynitrite scavenging activity. Similarly, 1,2dihydroparatocarpin A was prevented from oxidative damage by inhibition of peroxynitrite and NO production $[83,84]$.

A series of compounds were isolated and characterized from an ethyl acetate-soluble fraction of stem exudates of Angelica keiskei. Researchers further investigated the inhibitory effects of these compounds on the induction of EBV-EA (Epstein-Barr virus early antigen) by TPA in Raji cells. Among these compounds, xanthoangelol F, xanthoangelol $\mathrm{H}$, xanthoangelol, isobavachalcone, and 4hydroxyderricin demonstrated strong inhibitory effects on EBV-EA induction. In-depth studies showed that xanthoangelol $\mathrm{F}$ and isobavachalcone were able to inhibit activation of $( \pm)-(\mathrm{E})$-methyl-2-[(E)-hydroxyimino]-5-nitro-6methoxy-3- hexemide (NOR 1), an NO donor, as a primary screening test for antitumor-initiators [85]. Afterwards, Akihisa et al. isolated two new chalcones, xanthoangelols I and J, and both of them showed inhibitory abilities on EBV-EA induction by TPA and activation of NOR 1. Isobavachalcone was observed to inhibit growth of skin tumor cells in a twostage carcinogenesis test in mouse skin using DMBA and TPA as the inhibitor and promoter, respectively [86]. Moreover, isobavachalcone significantly inhibited the production of NO in lipopolysaccharide-activated macrophages [87]. And it is 
effective in preventing lipid peroxidation in rat liver microsomes and mitochondria induced by NADPH, ascorbate, $\mathrm{CCl}_{4}$, and so forth, $[88,89]$.

Furthermore, xanthohumol could modulate carcinogen metabolism through inhibition of phase 1 CyplA $\left(\mathrm{IC}_{50}=\right.$ $0.02 \mu \mathrm{M})$ and induction of phase $2 \mathrm{NAD}(\mathrm{P}) \mathrm{H}$ :quinone reductase $(\mathrm{CD}=1.7 \mu \mathrm{M})$. It was also tested for the potential to inhibit iNOS induction and COX-1 and COX2 activities with $\mathrm{IC}_{50}$ values of $12.9,16.6$, and $41.5 \mu \mathrm{M}$, respectively. Based on these results above, xanthohumol was additionally tested in an organ culture model using mouse mammary glands. It significantly inhibited chemically induced preneoplastic lesions with an $\mathrm{IC}_{50}$ value of $0.02 \mu \mathrm{M}$ [90].

ROS can cause DNA damages, which subsequently results in cancer initiation. In order to search for chemopreventive agents of natural origin to destroy ROS, Kaur et al. studied the fraction "Rlicca" isolated from Glycyrrhiza glabra, which was further identified as isoliquiritin apioside, for its effect against genotoxicity induced by $\mathrm{H}_{2} \mathrm{O}_{2}$ and 4NQO in Escherichia coli PQ37 using SOS chromotest and in human peripheral blood lymphocytes using the Comet assay. In SOS chromotest, "Rlicca" $(191 \mu \mathrm{M})$ was found to be effective in decreasing the SOS inducing potency of $\mathrm{H}_{2} \mathrm{O}_{2}(1.0 \mathrm{mM})$ and NQO $(20 \mu \mathrm{g} / \mathrm{mL})$ by $83.72 \%$ and $68.77 \%$, respectively. In the Comet assay, "Rlicca" of all the doses reduced the tail moment induced by $\mathrm{H}_{2} \mathrm{O}_{2}(25 \mu \mathrm{M})$ and NQO $(5 \mu \mathrm{g} / \mathrm{mL})$ by $88.04 \%$ and $76.64 \%$, respectively [91].

The formation of $\mathrm{Bcr}-\mathrm{Abl}$ oncogene is due to fusion between $\mathrm{Abl}$ tyrosine kinase gene and $\mathrm{Bcr}$ gene and a constitutively active Bcr-Abl tyrosine kinase plays a crucial role in the proliferation of chronic myelogenous leukemia cells. Xanthohumol showed in vitro activity against Bcr$\mathrm{Abl}(+)$ cells and clinical samples and retained cytotoxicity in imatinib mesylate-resistant K562 cells. It induced apoptosis, increase of p21 and p53 expression, and decrease of surviving levels in K562 cells. It also markedly inhibited Bcr-Abl expression at both mRNA and protein levels and caused elevation of intracellular ROS. Furthermore, xanthohumol inhibited leukemia cell invasion, metalloprotease production, and adhesion to endothelial cells, potentially preventing in vivo life-threatening complication of leukostasis and tissue infiltration by leukemic cells. Distinct from that of imatinib, this mechanism targets Bcr-Abl mRNA and protein and thus does not appear to be circumvented by Abl kinase mutations [92].

3.6. Cell Signal Transduction. Protein kinases or phosphokinase are enzymes that transfer $\gamma$-phosphate from ATP to an amino acid residue in proteins. Protein phosphorylation plays a prominent role in a wide range of cellular signal transduction pathways. And aberrant expression or activation of kinases can result in perturbation of relevant cellular processes, including cell growth, proliferation, and death. Protein kinases family is divided into tyrosine kinases and serine/threonine kinases.
Isoliquiritigenin was found to inhibit proliferation of prostate cancer cells through inhibition of ErbB3 signaling which belongs to tyrosine kinases. It reduced the protein and mRNA levels of ErbB3 dose dependently and showed no effect on HRG protein levels. It also inhibited HRG$\beta$-induced tyrosine phosphorylation of ErbB3, recruitment of the p85 regulatory subunit of PI3K to ErbB3, and Akt phosphorylation in DU145 cells [93].

Recently, Jing et al. found isobavachalcone could abrogate Akt signaling significantly, which played a critical role in its antiproliferative effects on human cancer cells. Results showed that this chalcone could bind to the ATP-binding pocket of Akt. Furthermore, isobavachalcone markedly abated Akt phosphorylation at Ser-473 and Akt kinase activity and thereby inhibited Akt downstream substrates and induced apoptosis [94].

It was reported that butein exhibited antiproliferative effects against tumor cells through suppression of the signal transducer and activator of transcription 3 (STAT3) activation pathway. Butein inhibited both constitutive and interleukin-6-inducible STAT3 activation in multiple myeloma cells through inhibition of activation of the upstream kinases c-Src, Janus-like kinasel (JAK1), and JAK2. Also, the induction of tyrosine phosphatase SHP-1 was involved in the action of this chalcone. It resulted in apoptosis by downregulating expression of STAT3-regulated gene products such as Bcl-xL, Bcl-2, cyclin D1, and Mcl-1. Butein markedly potentiate the apoptotic effects of thalidomide and velcade in multiple myeloma cells. Moreover, overexpression of constitutive active STAT3 significantly reduced the buteininduced apoptosis [95].

The ethanol extract of Helichrysum maracandicum exhibited strong antiproliferative activity against SENCAR mouse skin transformed cells and SENCAR mouse skin transformed tumor cells in vitro. Activity-guided fractionation of the extract led to the identification of isosalipurposide and its aglycone, naringenin chalcone as active substances. Further in vivo assay of two-stage carcinogenesis on mouse skin revealed that epidermal application isosalipurposide resulted in delayed formation of papillomas. It was also observed that administration of naringenin chalcone or isosalipurposide inhibited the expression of p38 mitogen-activated protein (MAP) kinase [96].

Transforming growth factor- $\beta$ (TGF- $\beta$ ) superfamily is known to regulate cellular tissue regeneration, differentiation, immune surveillance, angiogenesis, and apoptosis. Isocordoin was investigated on its effect on TGF- $\beta 1$ in mice with L5178Y lymphoma. Results showed that it exhibited antitumor activity through modulation of TGF- $\beta 1$ concentration in plasma and ascitis of lymphoma-bearing mice [97].

Alkaline phosphatase (ALP) dephosphorylates proteins which are involved in cell growth and differentiation, apoptosis, and cell migration. Abnormal expression of ALP isoenzymes has been found in malignant tissues, being often established as a useful prognostic indicator. Guerreiro et al. reported that incubation with $10 \mu \mathrm{M}$ xanthohumol $\left(\mathrm{IC}_{50}\right)$ in MCF-7 cells decreased proliferation and RNA and protein expression of intestinal ALP, but not TNS-ALP (tissue nonspecific ALP). The modulation of ALP by xanthohumol may 
be relevant to the development of therapeutic and preventive strategies against breast cancer [98].

3.7. Antiinvasion and Antimetastasis. Tumor invasion and metastasis are considered as the main therapeutic challenges in oncology. Invasion is the result of a disequilibrium between the expression of invasion promoter and invasion suppressor genes, in a sense that carcinomas either upregulate the promoters or downregulate the suppressors [99]. The tumorsecreted proteases not only degrade barriers (basement membrane and interstitial matrix) against invasion, but also cleave off cell surface glycoproteins which are essential for cell-cell/matrix adhesion. Malignant tumor cells intravasate into the blood vessels by passive transport and intravasation into new environment, which establishes a metastasis [100]. How to overcome chemotherapy resistance of invasion and metastasis is a big challenge in oncology.

Xanthohumol was able to inhibit the invasion of MCF7/6 and of T47-D breast cancer cells. Aggregation assay showed that xanthohumol could stimulate aggregation of MCF 7/6 cells in suspension via restoring the function of E-cadherin/catenin complex, a powerful invasion suppressor [101]. Moreover, in T47-D cells xanthohumol stimulated the transcription and translocation of the endoplasmic reticulum chaperone GRP78, a maker for endoplasmic reticulum stress. The stress transducers PERK, IRE1 and ATF6 were activated as well. Xanthohumol motivated the phosphorylation of eIF2, the splicing of XBP1 and the cleavage of ATF6. The sustained endoplasmic reticulum stress led to changes of apoptosis-related factors and the susceptibility of xanthohumol-induced apoptosis appeared to associate with the GRP78 expression levels. Accordingly, xanthohumol inhibited invasion of breast cancer cells through stimulation of the E-cadherin mediated cell-cell adhesion and apoptosis in the number of invasive cells by promoting a chronic stress condition [102].

Also, it was reported that xanthohumol targeted the endoplasmic reticulum and activated the unfolded protein response and thus induced apoptosis of chronic lymphocytic leukemia cells from 18 patient samples. The apoptosis was accompanied by induction of GRP78 and Hsp70 protein levels and by sustained phosphorylation of eIF $2 \alpha$, indicating the involvement of PERK. It also induced splicing of the XBP1 mRNA without activation of ATF6. In addition, xanthohumol showed proteasome inhibitory activity [103] and exerted similar effects on B-cell acute lymphocytic leukemia cells in vitro and in all xenografts mouse model. Treatment with xanthohumol impaired cell migration and invasion, with the contaminant downregulation of FAK, Akt, and NF- $\kappa \mathrm{B}$ expression [104].

Ngameni et al. studied the inhibitory effects of isolates from the twig of Dorstenia turbinate on MMP-2 secretion in brain tumor-derived U87 glioblastoma cells. Kanzonol $\mathrm{C}$ and 4-hydroxylonchocarpin exhibited strong inhibitory activities comparable to the documented MMP secretion inhibitors CHL and EGCg [105]. Ngameni et al. found that isobavachalcone, paratocarpin $\mathrm{C}$, stipulin, and dorsmannin A displayed even higher inhibitory effects on MMP secretion than 4-hydroxylonchocarpin and kanzonol $\mathrm{C}$ as well as $\mathrm{CHL}$ and EGCg, with maximum inhibition ranging from $60 \%$ to $80 \%$ at $250 \mu \mathrm{M}$ [106].

Bioassay-directed fractionation of the extract from the roots of Angelica keiskei yielded two active compounds, xanthoangelol and 4-hydroxyderricin. Studies on xanthoangelol showed that it inhibited tumor growth in LLC-bearing mice as well as lung metastasis and prolonged survival time in carcinectomized mice at a daily dose of $50 \mathrm{mg} / \mathrm{kg}$. Treatment with 50 or $100 \mathrm{mg} / \mathrm{kg}$ daily also inhibited liver metastasis and the growth of metastasized tumor cells [107]. Similarly, 4-hydroxyderricin at a dose of $50 \mathrm{mg} / \mathrm{kg} \times 2$ /day orally inhibited the tumor growth in subcutaneous LLC-implanted mice and inhibited the lung metastasis and prolonged the survival time in mice after the removal of subcutaneous tumors by surgical operation. It also controlled the reduction of lymphocytes, $\mathrm{CD}^{+}, \mathrm{CD}^{+}$, and natural killer-T (NK$\mathrm{T})$ cells in the spleen of tumor-removed mice [108]. The antitumor and antimetastatic activity of xanthoangelol and 4hydroxyderricin may be associated with inhibition of DNA synthesis, inhibition of tumor-induced neovascularization by reducing formation of capillary-like tubes in human umbilical vein endothelial cells (HUVECs), and suppressing binding of VEGF to HUVECs $[107,108]$.

When examined in a pulmonary metastasis model of mouse renal cell carcinoma, isoliquiritigenin exhibited significant activity without any weight loss or leukocytopenia. It suppressed proliferation of carcinoma cells in vitro, potentiated NO production by lipopolysaccharide-stimulated macrophages, and enhanced cytotoxicity of splenic lymphocytes in vitro. In addition, it prevented severe leukocytopenia induced by administration of 5-fluorouracil [109].

3.8. Regulation of Cell Cycle. Cell cycle is a series of complicated and fine adjustment processes which lead to cellular differentiation, growth, and programmed death. And aberrant regulation of cell cycle is regarded as one of the most distinguishing marks. Cyclin-dependent kinases (CDKs) are a family of proteins that plays an essential role in regulating cell cycle, and activation of CDK is controlled by cyclins and cyclin-dependent kinase inhibitors (CKIs) [110].

Yun et al. conducted a study to confirm tumor cell growth inhibitory effect of panduratin A in androgen-independent human prostate cancer cells PC-3 and DU145. Panduratin A treatment inhibited cell growth with an $\mathrm{IC}_{50}$ of $13.5-14 \mu \mathrm{M}$ and had none to little effect on normal human prostate epithelial cells. It mediated apoptosis via both mitochondrial and death receptor pathways. Treatment by panduratin A led to G2/M phase arrest in a dose-dependent manner by modulating expression of $\mathrm{G} 2 / \mathrm{M}$ regulatory molecules, including induction of p21/WAF1 and p27/Kip1 and downregulation of CDKs 2, 4, and 6 as well as decrease in cyclins D1 and E [111]. Similarly, isoliquiritigenin exhibited significant inhibitory effects against prostate cancer cell lines DU145 and LNCaP and caused S and G2/M phase arrest due to the expression enhancement of GADD153 mRNA and protein associated with cell cycle arrest. This compound also 
stimulated transcriptional activity of GADD153 promoter dose dependently [112].

Isoliquiritigenin was demonstrated to inhibit the proliferation of U87 glioma cells in vitro, and it caused cell cycle arrest at $\mathrm{S}$ and $\mathrm{G} 2 / \mathrm{M}$ phases and induced caspasemediated apoptosis pathway. Further examination showed p21/WAF1 and p27 were upregulated [113]. Similar activity of isoliquiritigenin was also found in human lung cancer cells A549, in which cell cycle arrest at G2/M phase was observed. cDNA arrays and real-time quantitative RT-PCR revealed isoliquiritigenin enhanced p21/WAF1 expression with no change of p53 [114]. However, Hsu et al. observed that isoliquiritigenin inhibited proliferation through p53 and Fas/FasL apoptotic system in A549 cells. An ELISA assay showed that the significant increase of the expression of p53 and p21/WAF1 protein led to cell cycle arrest in the G1 phase [115].

Isoliquiritigenin caused a G2/M-phase arrest in HepG2 cells and upregulated p53, p21/WAF1, Fas/APO-1 receptor, Fas ligand, Bax, and NOXA. The enhancement of p21/WAF1, Fas/APO-1, Bax, and NOXA was decreased in HepG2 cells that lack functional p53. And when the transcriptional activity of p53 was blocked, HepG2 cells became significantly more resistant to isoliquiritigenin [116].

Rao et al. synthesized 10 structurally related $2^{\prime}$-oxygenated chalcone derivatives including $2^{\prime}$-hydroxy-2,3, $4^{\prime}, 6^{\prime}$ tetramethoxychalcone. The in vitro cytotoxicity against the tumor cells such as Jurkat, U937 cells, and normal cells PHA stimulated primary peripheral blood mononuclear cells (PBMCs) were investigated. This chalcone showed strong inhibitory activity toward both Jurkat and U937 cell lines, with $\mathrm{IC}_{50}$ values of $1.7 \mu \mathrm{M}$ and $1.5 \mu \mathrm{M}$, respectively. The growth of normal cells PHA stimulated PBMCs was also inhibited, but relatively less sensitive to that of tumor cells. Cell cycle analysis of U937 showed that this chalcone caused a $\mathrm{G} 2 / \mathrm{M}$ arrest with a concomitant decrease of cells in the $S$ phase of cell cycle [117]. This chalcone was also a selective cytotoxic agent in human lung cancer cells. Among the 3 lungs cancer cell lines examined, $2^{\prime}$-hydroxy$2,3,4^{\prime}, 6^{\prime}$-tetramethoxychalcone was more sensitive to A549 cells than H1299 and H1355. In A549 cells, it induced G1 cell cycle arrest and upregulated tumor suppresser genes p21 and p53 and downregulated cell-cycle regulatory proteins phosphorylation of $\mathrm{cdc} 2\left(\mathrm{Tyr}^{15}\right.$ and $\mathrm{Tyr}^{161}$ ) and $\mathrm{Rb}$ $\left(\operatorname{Ser}^{795}\right.$ and Ser ${ }^{807 / 811}$ ), which may be one of its molecular mechanisms. In addition, in vivo data demonstrated that this chalcone acted as a tumor growth suppressing agent [118].

In a report published in 2004, licochalcone A was found to induce growth control and apoptosis on androgenindependent p53-null PC-3 prostate cancer cells. It induced modest level of apoptosis but caused strong influence on cell cycle progression arresting cells in G2/M through suppression of cyclin B1 and cdc2. They also found that licochalcone A inhibited phosphorylation of Rb, specially phosphorylation at 8780 without effect on that of T821. Moreover, licochalcone A could downregulate the expression of transcription factor
E2F, reduce cyclin D1, and downregulate CDKs 4 and 6 while increasing expression of cyclin E [119]. In addition, isocordoin was found to be able to block the cell cycle of cancer prostate cell PC-3, and the percentages of cells in G1, G2, and S phase were 26.0, 53.3, and 20.5, respectively [27].

3.9. Antiangiogenesis. Angiogenesis is a process producing new blood vessels by making use of preexist vessels. The growth and metastasis of most malignant solid tumors depend on angiogenesis, by which nutrients and oxygen needed for growth can be provided.

Zhu et al. studied the potential antiangiogenesis effects of $2^{\prime}, 4^{\prime}$-dihydroxy-3',5'-dimethyl- $6^{\prime}$-methoxychalcone in vitro as well as in vivo. It reversibly inhibited vascular endothelial growth factor receptor (VEGF receptor, KDR) tyrosine kinase phosphorylation with no influence on epidermal growth factor receptor tyrosine kinase phosphorylation. Mitogenactivated protein kinase and AKT activation of KDR signal transduction was inhibited as well. Systemic administration of this chalcone at nontoxic doses to nude mice resulted in inhibition of subcutaneous tumor growth of human hepatocarcinoma Bel7402 as well as lung cancer GLC-82 xenografts and a decrease of tumor vessel density [120].

The antiangiogenic property of xanthohumol was tested in an in vitro system. Fragments of placental vessels were cultured in the presence or absence of the compounds for 3 weeks in fibrin gels; xanthohumol induced a dosedependent reduction of newly formed capillary growth at a concentration range of $0.5-10 \mu \mathrm{M}\left(\mathrm{IC}_{50}\right.$ value of $\left.2.2 \mu \mathrm{M}\right)$. Xanthohumol also inhibited migration of HMEC-1 cells (immortalised human microvascular endothelial cell line) after wounding in a wound closure assay, with an $\mathrm{IC}_{50}$ value of $0.03 \mu \mathrm{M}$. Moreover, it effectively inhibited microcapillary tube formation of HMEC-1 cells at 1,5 , and $10 \mu \mathrm{M}$, respectively. Intravital microscopy was used as an in vivo model to investigate the effect of xanthohumol on tumor angiogenesis in vivo. Subcutaneous application of xanthohumol for 7 and 14 days, respectively, resulted in inhibition of the growth of breast tumor xenografts by $46 \%$ and $83 \%$ and reduction of the size of tumors by $30 \%$ and $56 \%$, respectively, in comparison with the untreated control group. Concomitantly, xanthohumol treatment for 14 days reduced tumor-induced neovascularization by $33 \%$ in comparison with the untreated control group [121, 122].

Furthermore, xanthohumol showed antiangiogenic property in the growth of a vascular tumor in vivo. This compound repressed both the NF- $\kappa \mathrm{B}$ and Akt pathways in endothelial cells. It was also shown that xanthohumol interfered with several steps of the angiogenic process, including invasion and migration, growth, and formation of a network of tubular-like structures [121, 123]. Xanthohumol inhibited cell proliferation in acute and chronic myelogenous leukemia cell lines, which was linked with induction of apoptosis, reduction of VEGF secretion, decrease of invasion, and metalloprotease production. Accordingly, xanthohumol could prevent in vivo life-threatening complications of leukostasis and tissue infiltration [124]. In addition, xanthohumol at 
$10 \mu \mathrm{M}$ markedly decreased tumor cells viability and invasion activity and potentiated apoptosis of HUVEC (human umbilical vein endothelial cell) and SMC (human fetal aortic smooth muscles cell) cells. Xanthohumol of 5 and $10 \mu \mathrm{M}$ also led to a significant reduction of capillary-like structures, when HUVECs were cultured on growth factor reducedMatrigel-coated plates. However, xanthohumol caused an increase of the number of cord structures when HUVECs were cocultured with SMC. Furthermore, incubation with xanthohumol led to the reduction of activity of NF- $\kappa$ B in both cell types [125].

\subsection{Other Targets}

3.10.1. Fibroblasts. Samoszuk et al. investigated whether butein could inhibit the clonogenic growth of small numbers of breast cancer cells co-cultured with fibroblasts in vitro, and fibroblasts are commonly believed to play an essential role in promoting the growth of breast cancer cells,. The clonogenic growth of primary breast cancer cells was significantly inhibited when co-cultured with fibroblasts pretreated with a fixed dose of butein [128].

3.10.2. Redifferentiation. Isoliquiritigenin inhibited HL-60 cells proliferation and decreased the iROS (intracellular ROS) levels dose dependently without an increase of the lethality rate. The treatment with $10 \mu \mathrm{g} / \mathrm{mL}$ isoliquiritigenin in $72 \mathrm{~h}$ led to a typical differentiated morphology in HL-60 cells, including a decrease of karyoplasmic ratio and an increase of kidney-shaped nuclear cells. In addition, the positive rate of CD11b and CD14 cells increased significantly and the NBT reductive activity increased 2 - and 3 -folds as compared to that of the control group. These results indicated isoliquiritigenin could induce monocytic differentiation in leukemia cells [126].

3.10.3. DNA Topoisomerase II. Due to the rapidly proliferative property of tumors, the content of topoisomerase II they need is far above that of normal cells. Therefore, inhibition of topoisomerase II results in limitation of proliferation, which has become an efficient target [130]. Pauferrol A, a chalcone trimer with a cylcobutane ring, isolated from the stems of Caesalpinia ferrea Mart., exhibited strong inhibitory activity against human topoisomerase II with an $\mathrm{IC}_{50}$ value of $2.1 \mu \mathrm{M}$ and apoptosis activity in human leukemia HL-60 cells with an $\mathrm{IC}_{50}$ value of $5.2 \mu \mathrm{M}$ [129].

3.10.4. Supplement for Cisplatin Chemotherapy. Isoliquiritigenin has the potential to act as a beneficial supplement during cisplatin chemotherapy. The single administration of isoliquiritigenin markedly reduced the size of the solid tumors in CT- 26 cell-inoculated BALB/c mice. The treatment also caused the reduction of the viability and DNA synthesis of CT-26 murine colon cancer cells dose dependently. Isoliquiritigenin not only had no effects on the therapeutic efficacy of cisplatin but suppressed kidney damage caused by cisplatin, characterized by increases in serum creatinine and blood urea nitrogen, as well as liver damage characterized by increases in serum alanine aminotransferase and aspartate aminotransferase. Furthermore, repeated oral administration of isoliquiritigenin prior to cisplatin treatment significantly inhibited cisplatin-induced increases in serum nitric oxide and tissue lipid peroxidation levels and recovered depleted GSH levels in the tissues [127].

\section{Conclusion}

Tumors, both benign and malignant, constitute a group of well-known refractory diseases which have been baffling scientists for quite a long time. Up to date, medicinal scientists have made a lot of efforts trying to overcome this millennium problem, and as a result, many new chemical drugs have been developed. Although these drugs currently available are favorable in alleviation of the condition and adjuvant chemotherapy, most of them have a limited application because of their less well effectiveness, severe toxicity, and high manufacturing cost. Herbal medicines and natural products isolated therefrom, for example, flavonoids, are being highly expected due to their novel structure, distinctive mechanism, satisfactory effectiveness, and reliable safety. Many investigations have shown the advantageous activities and multifarious mechanisms of flavonoids. Chalcones (1,3diaryl-2-propen-1-ones) are a kind of open chain flavonoids, which makes their structures more diversified than other types. In the past decades, a number of chalcones were proved to have antitumor potential either in vitro or in vivo, and a large proportion of underlying mechanisms have been explained. Based on the current studies, chalcones are highly multifunctional and their targets cover almost all of the actions of tumor cells, including growth, proliferation, invasion, and metastasis. Moreover, researchers have discovered several chalcones with significant antitumor activity both in vitro and in vivo, such as xanthohumol, isoliquiritigenin, and butein. These chalcones can be served as promising lead compounds for further drug development. However, it should also be noted that much of the pharmacological potential of chalcones is still not utilized due to some unclear mechanisms, and more working such as fundamental and clinical researches should be done to make best use of these natural products.

\section{References}

[1] V. R. Yadav, S. Prasad, B. Sung, and B. B. Aggarwal, "The role of chalcones in suppression of NF- $\kappa \mathrm{B}$-mediated inflammation and cancer," International Immunopharmacology, vol. 11, no. 3, pp. 295-309, 2011.

[2] S. V. Kostanecki and J. Tabor, "Ueber die sechs isomeren Monooxybenzalacetophenone (Monooxychalkone)," Berichte Der Deutschen Chemischen Gesellschaft, vol. 32, no. 2, pp. 19211926, 1899.

[3] Ø.M. Andersen and K. R. Markham, FLAVONOIDS: Chemistry, Biochemistry and Applications, CRC Press, 2006.

[4] S. A. Chowdhury, K. Kishino, R. Satoh et al., "Tumor-specificity and apoptosis-inducing activity of stilbenes and flavonoids," Anticancer Research, vol. 25, no. 3 B, pp. 2055-2063, 2005. 
[5] S. N. A. Malek, C. W. Phang, H. Ibrahim, N. A. Wahab, and K. S. Sim, "Phytochemical and cytotoxic investigations of Alpinia mutica rhizomes," Molecules, vol. 16, no. 1, pp. 583-589, 2011.

[6] X. Zi and A. R. Simoneau, "Flavokawain A, a novel chalcone from kava extract, induces apoptosis in bladder cancer cells by involvement of Bax protein-dependent and mitochondriadependent apoptotic pathway and tumor growth in mice," Cancer Research, vol. 65, no. 8, pp. 3479-3486, 2005.

[7] N. W. Nwet, S. Awale, H. Esumi, Y. Tezuka, and S. Kadota, "Bioactive secondary metabolites from Boesenbergia pandurata of Myanmar and their preferential cytotoxicity against human pancreatic cancer PANC-1 cell line in nutrient-deprived medium," Journal of Natural Products, vol. 70, no. 10, pp. 15821587, 2007.

[8] J. Chen, Y. Li, L. Q. Yang, Y. Z. Li, Z. B. Nan, and K. Gao, "Biological activities of flavonoids from pathogenic-infected Astragalus adsurgens," Food Chemistry, vol. 131, no. 2, pp. 546551, 2012.

[9] C. L. Ye, J. W. Liu, D. Z. Wei, Y. H. Lu, and F. Qian, "In vitro anti-tumor activity of $2^{\prime}, 4^{\prime}$-dihydroxy- $6^{\prime}$ - methoxy- $3^{\prime}, 5^{\prime}$ dimethylchalcone against six established human cancer cell lines," Pharmacological Research, vol. 50, no. 5, pp. 505-510, 2004.

[10] E. C. Amor, I. M. Villaseñor, R. Antemano, Z. Perveen, G. P. Concepcion, and M. I. Choudhary, "Cytotoxic C-methylated chalcones from Syzygium samarangense," Pharmaceutical Biology, vol. 45, no. 10, pp. 777-783, 2007.

[11] M. J. Simirgiotis, S. Adachi, S. To et al., "Cytotoxic chalcones and antioxidants from the fruits of Syzygium samarangense (Wax Jambu)," Food Chemistry, vol. 107, no. 2, pp. 813-819, 2008.

[12] F. Li, S. Awale, Y. Tezuka, and S. Kadota, "Cytotoxic constituents from Brazilian red propolis and their structure-activity relationship," Bioorganic and Medicinal Chemistry, vol. 16, no. 10, pp. 5434-5440, 2008.

[13] X. Yu, W. Wang, and M. Yang, "Antioxidant activities of compounds isolated from Dalbergia odorifera T. Chen and their inhibition effects on the decrease of glutathione level of rat lens induced by UV irradiation," Food Chemistry, vol. 104, no. 2, pp. 715-720, 2007.

[14] G. Yoon, Y. D. Jung, and S. H. Cheon, "Cytotoxic allyl retrochalcone from the roots of Glycyrrhiza inflata," Chemical and Pharmaceutical Bulletin, vol. 53, no. 6, pp. 694-695, 2005.

[15] M. C. Li, Z. Yao, Y. Takaishi, S. A. Tang, and H. Q. Duan, "Isolation of novel phenolic compounds with multidrug resistance (MDR) reversal properties from Onychium japonicum," Chemistry and Biodiversity, vol. 8, no. 6, pp. 1112-1120, 2011.

[16] U. Prawat, D. Phupornprasert, A. Butsuri, A. W. Salae, S. Boonsri, and P. Tuntiwachwuttikul, "Flavonoids from Friesodielsia discolor," Phytochemistry Letters, vol. 5, no. 4, pp. 809-813, 2012.

[17] L. Cui, T. T. Phuong, S. L. Hyun et al., "Four new chalcones from Erythrina abyssinica," Planta Medica, vol. 74, no. 4, pp. 422-426, 2008.

[18] W. S. Wang, Y. W. Zhou, Y. H. Ye, and M. L. Li, "A novel prenylchalcone from Humulus lupulus," Chinese Chemical Letters, vol. 15, no. 10, pp. 1195-1196, 2004.

[19] S. Vogel and J. Heilmann, "Synthesis, cytotoxicity, and antioxidative activity of minor prenylated chalcones from Humulus lupulus," Journal of Natural Products, vol. 71, no. 7, pp. 1237-1241, 2008.

[20] S. Vogel, S. Ohmayer, G. Brunner, and J. Heilmann, "Natural and non-natural prenylated chalcones: synthesis, cytotoxicity and anti-oxidative activity," Bioorganic and Medicinal Chemistry, vol. 16, no. 8, pp. 4286-4293, 2008.

[21] L. Delmulle, A. Bellahcène, W. Dhooge et al., "Anti-proliferative properties of prenylated flavonoids from hops (Humulus lupulus L.) in human prostate cancer cell lines," Phytomedicine, vol. 13, no. 9-10, pp. 732-734, 2006.

[22] H. L. Jae, N. I. Baek, S. H. Kim et al., "A new cytotoxic prenylated chalcone from Sophora flavescens," Archives of Pharmacal Research, vol. 30, no. 4, pp. 408-411, 2007.

[23] C. C. Shen, T. W. Lin, Y. L. Huang, S. T. Wan, B. J. Shien, and C. C. Chen, "Phenolic constituents of the roots of Sophora flavescens," Journal of Natural Products, vol. 69, no. 8, pp. 12371240, 2006.

[24] X. H. Su, C. Y. Li, Y. J. Zhong, Z. P. Yuan, Y. F. Li, and B. Liang, "A new prenylated chalcone from the seeds of Millettia pachycarpa," Chinese Journal of Natural Medicines, vol. 10, no. 3, pp. 222-225, 2012.

[25] H. Ye, A. Fu, W. Wu et al., "Cytotoxic and apoptotic effects of constituents from Millettia pachycarpa Benth," Fitoterapia, vol. 83, no. 8, pp. 1402-1408, 2012.

[26] S. C. Fang, C. L. Hsu, Y. S. Yu, and G. C. Yen, "Cytotoxic effects of new geranyl chalcone derivatives isolated from the leaves of Artocarpus communis in SW 872 human liposarcoma cells," Journal of Agricultural and Food Chemistry, vol. 56, no. 19, pp. 8859-8868, 2008.

[27] R. Borges-Argáez, L. Balnbury, A. Flowers et al., "Cytotoxic and antiprotozoal activity of flavonoids from Lonchocarpus spp," Phytomedicine, vol. 14, no. 7-8, pp. 530-533, 2007.

[28] G. M. De Andrade Cunha, J. B. Fontenele, H. V. Nobre Júnior et al., "Cytotoxic activity of chalcones isolated from lonchocarpus sericeus (Pocr.) Kunth," Phytotherapy Research, vol. 17, no. 2, pp. 155-159, 2003.

[29] Y. Kang, M. A. Park, M. Y. Cho, K. H. Lee, and J. A. Kim, "Cytotoxic effect of chalcone derivatives in MCF-7 human breast cancer and HT-1080 human fibrosarcoma cells," Yakhak Hoechi, vol. 54, no. 1, pp. 27-31, 2010.

[30] S. Takaoka, H. Hibasami, K. Ogasawara, and N. Imai, "Chalcones from Angelica keiskei induce apoptosis in stomach cancer cells," Journal of Herbs, Spices and Medicinal Plants, vol. 14, no. 3-4, pp. 166-174, 2008.

[31] Q. J. Zhang, Y. B. Tang, R. Y. Chen, and D. Q. Yu, "Three new cytotoxic Diels-Alder-type adducts from Morus australis," Chemistry and Biodiversity, vol. 4, no. 7, pp. 1533-1540, 2007.

[32] X. Q. Cui, L. Wang, R. Y. Yan, Y. X. Tan, R. Y. Chen, and D. Q. Yu, "A new Diels-Alder type adduct and two new flavones from the stem bark of Morus yunanensis Koidz," Journal of Asian Natural Products Research, vol. 10, no. 4, pp. 315-318, 2008.

[33] M. C. Li, Z. Yao, Y. W. Zhang, Y. Takaishi, and H. Q. Duan, "A novel chalcone derivative from Onychium japonicum," Chinese Chemical Letters, vol. 18, no. 7, pp. 840-842, 2007.

[34] L. Wirasathien, T. Pengsuparp, M. Moriyasu, K. Kawanishi, and R. Suttisri, "Cytotoxic C-benzylated chalcone and other constituents of Ellipeiopsis cherrevensis," Archives of Pharmacal Research, vol. 29, no. 6, pp. 497-502, 2006.

[35] L. K. Mdee, S. O. Yeboah, and B. M. Abegaz, "Rhuschalcones IIVI, five new bichalcones from the root bark of Rhus pyroides," Journal of Natural Products, vol. 66, no. 5, pp. 599-604, 2003.

[36] M. O. Hengartner, "The biochemistry of apoptosis," Nature, vol. 407, no. 6805, pp. 770-776, 2000.

[37] W. R. Sellers and D. E. Fisher, "Apoptosis and cancer drug targeting," Journal of Clinical Investigation, vol. 104, no. 12, pp. 1655-1661, 1999. 
[38] A. Chiarugi and M. A. Moskowitz, "Cell biology: PARP-1: a perpetrator of apoptotic cell death?" Science, vol. 297, no. 5579, pp. 200-201, 2002.

[39] K. Tabata, K. Motani, N. Takayanagi et al., "Xanthoangelol, a major chalcone constituent of Angelica keiskei, induces apoptosis in neuroblastoma and leukemia cells," Biological and Pharmaceutical Bulletin, vol. 28, no. 8, pp. 1404-1407, 2005.

[40] J. M. Yun, H. Kwon, H. Mukhtar, and J. K. Hwang, "Induction of apoptosis by panduratin A isolated from Kaempferia pandurata in human colon cancer HT-29 cells," Planta Medica, vol. 71, no. 6, pp. 501-507, 2005.

[41] A. Thorburn, K. Behbakht, and H. Ford, "TRAIL receptortargeted therapeutics: resistance mechanisms and strategies to avoid them," Drug Resistance Updates, vol. 11, no. 1-2, pp. 17-24, 2008.

[42] E. Szliszka and W. Krol, "The role of dietary polyphenols in tumor necrosis factor-related apoptosis inducing ligand (TRAIL)-induced apoptosis for cancer chemoprevention," European Journal of Cancer Prevention, vol. 20, no. 1, pp. 63-69, 2011.

[43] N. Kim, "Butein sensitizes human leukemia cells to apoptosis induced by tumor necrosis factor-related apoptosis inducing ligand (TRAIL)," Archives of Pharmacal Research, vol. 31, no. 9, pp. 1179-1186, 2008.

[44] E. Szliszka, Z. P. Czuba, B. Mazur, L. Sedek, A. Paradysz, and W. Krol, "Chalcones enhance TRAIL-induced apoptosis in prostate cancer cells," International Journal of Molecular Sciences, vol. 11, no. 1, pp. 1-13, 2010.

[45] E. Szliszka, Z. P. Czuba, B. Mazur, A. Paradysz, and W. Krol, "Chalcones and dihydrochalcones augment TRAIL-mediated apoptosis in prostate cancer cells," Molecules, vol. 15, no. 8, pp. 5336-5353, 2010.

[46] E. Szliszka, D. Jaworska, M. Ksek, Z. P. Czuba, and W. Król, "Targeting death receptor TRAIL-R2 by chalcones for TRAILinduced apoptosis in cancer cells," International Journal of Molecular Sciences, vol. 13, no. 11, pp. 15343-15359, 2012.

[47] T. Ohtsuki, H. Kikuchi, T. Koyano, T. Kowithayakorn, T. Sakai, and M. Ishibashi, "Death receptor 5 promoter-enhancing compounds isolated from Catimbium speciosum and their enhancement effect on TRAIL-induced apoptosis," Bioorganic and Medicinal Chemistry, vol. 17, no. 18, pp. 6748-6754, 2009.

[48] T. Yoshida, M. Horinaka, M. Takara et al., "Combination of isoliquiritigenin and tumor necrosis factor-related apoptosisinducing ligand induces apoptosis in colon cancer HT29 cells," Environmental Health and Preventive Medicine, vol. 13, no. 5, pp. 281-287, 2008.

[49] S. Desagher and J. C. Martinou, "Mitochondria as the central control point of apoptosis," Trends in Cell Biology, vol. 10, no. 9, pp. 369-377, 2000.

[50] Y. F. Kuo, Y. Z. Su, Y. H. Tseng, S. Y. Wang, H. M. Wang, and P. J. Chueh, "Flavokawain B, a novel chalcone from Alpinia pricei Hayata with potent apoptotic activity: involvement of ROS and GADD153 upstream of mitochondria-dependent apoptosis in HCT116 cells," Free Radical Biology and Medicine, vol. 49, no. 2, pp. 214-226, 2010.

[51] Y. Tang, X. Li, Z. Liu, A. R. Simoneau, J. Xie, and X. Zi, "Flavokawain B, a kava chalcone, induces apoptosis via upregulation of death-receptor 5 and Bim expression in androgen receptor negative, hormonal refractory prostate cancer cell lines and reduces tumor growth," International Journal of Cancer, vol. 127, no. 8, pp. 1758-1768, 2010.
[52] E. Lin, W. H. Lin, S. Y. Wang et al., "Flavokawain B inhibits growth of human squamous carcinoma cells: involvement of apoptosis and cell cycle dysregulation in vitro and in vivo," Journal of Nutritional Biochemistry, vol. 23, no. 4, pp. 368-378, 2011.

[53] Y. Meng, J. Zhong, and H. Sun, "Effects of Ashitaba chalcone on caspase-3 and Bax protein expressions of mouse hepatocarcinoma cells," Carcinogenesis, Teratogenesis and Mutagenesis, vol. 23, no. 1, pp. 50-53, 2011.

[54] C. L. Ye, F. Qian, D. Z. Wei, Y. H. Lu, and J. W. Liu, "Induction of apoptosis in K562 human leukemia cells by $2^{\prime}, 4^{\prime}$ - dihydroxy- 6 ' methoxy-3', $5^{\prime}$-dimethylchalcone," Leukemia Research, vol. 29, no. 8, pp. 887-892, 2005.

[55] J. I. Jung, S. S. Lim, H. J. Choi et al., "Isoliquiritigenin induces apoptosis by depolarizing mitochondrial membranes in prostate cancer cells," Journal of Nutritional Biochemistry, vol. 17, no. 10, pp. 689-696, 2006.

[56] K. Motani, K. Tabata, Y. Kimura et al., "Proteomic analysis of apoptosis induced by xanthoangelol, a major constituent of Angelica keiskei, in neuroblastoma," Biological and Pharmaceutical Bulletin, vol. 31, no. 4, pp. 618-626, 2008.

[57] N. M. Isa, A. B. Abdul, S. I. Abdelwahab et al., "Boesenbergin A, a chalcone from Boesenbergia rotunda induces apoptosis via mitochondrial dysregulation and cytochrome c release in A549 cells in vitro: involvement of HSP70 and Bcl2/Bax signalling pathways," Journal of Functional Foods, vol. 5, no. 1, pp. 87-97, 2012.

[58] R. Nishimura, K. Tabata, M. Arakawa et al., "Isobavachalcone, a chalcone constituent of Angelica keiskei, induces apoptosis in neuroblastoma," Biological and Pharmaceutical Bulletin, vol. 30, no. 10, pp. 1878-1883, 2007.

[59] L. Pan, H. Becker, and C. Gerhäuser, "Xanthohumol induces apoptosis in cultured 40-16 human colon cancer cells by activation of the death receptor- and mitochondrial pathway," Molecular Nutrition and Food Research, vol. 49, no. 9, pp. 837843, 2005.

[60] S. Kizaka-Kondoh, M. Inoue, H. Harada, and M. Hiraoka, "Tumor hypoxia: a target for selective cancer therapy," Cancer Science, vol. 94, no. 12, pp. 1021-1028, 2003.

[61] P. Vaupel and A. Mayer, "Hypoxia in cancer: significance and impact on clinical outcome," Cancer and Metastasis Reviews, vol. 26, no. 2, pp. 225-239, 2007.

[62] J. M. Brown and W. R. Wilson, "Exploiting tumour hypoxia in cancer treatment," Nature Reviews Cancer, vol. 4, no. 6, pp. 437447, 2004.

[63] N. T. Dat, X. Jin, K. Lee, Y. S. Hong, Y. H. Kim, and J. J. Lee, "Hypoxia-inducible factor-1 inhibitory benzofurans and chalcone-derived Diels-Alder adducts from Morus species," Journal of Natural Products, vol. 72, no. 1, pp. 39-43, 2009.

[64] B. Srinivasan, T. E. Johnson, and C. Xing, "Chalcone-based inhibitors against hypoxia-inducible factor 1: structure activity relationship studies," Bioorganic and Medicinal Chemistry Letters, vol. 21, no. 1, pp. 555-557, 2011.

[65] K. Goto, T. Asai, S. Hara et al., "Enhanced antitumor activity of xanthohumol, a diacylglycerol acyltransferase inhibitor, under hypoxia," Cancer Letters, vol. 219, no. 2, pp. 215-222, 2005.

[66] F. Mercurio and A. M. Manning, "Multiple signals converging on NF- $\kappa \mathrm{B}$," Current Opinion in Cell Biology, vol. 11, no. 2, pp. 226-232, 1999.

[67] F. Mercurio, H. Zhu, B. W. Murray et al., "IKK-1 and IKK-2: cytokine-activated $\mathrm{I} \kappa \mathrm{B}$ kinases essential for NF- $\kappa \mathrm{B}$ activation," Science, vol. 278, no. 5339, pp. 860-866, 1997. 
[68] A. S. Baldwin, "Control of oncogenesis and cancer therapy resistance by the transcription factor NF- $\kappa \mathrm{B}$," Journal of Clinical Investigation, vol. 107, no. 3, pp. 241-246, 2001.

[69] M. K. Pandey, S. K. Sandur, B. Sung, G. Sethi, A. B. Kunnumakkara, and B. B. Aggarwal, "Butein, a tetrahydroxychalcone, inhibits nuclear factor (NF) $-\kappa B$ and NF- $\kappa$ B-regulated gene expression through direct inhibition of $\mathrm{I} \kappa \mathrm{B} \alpha$ kinase $\beta$ on cysteine 179 residue," Journal of Biological Chemistry, vol. 282, no. 24, pp. 17340-17350, 2007.

[70] K. B. Harikumar, A. B. Kunnumakkara, K. S. Ahn et al., "Modification of the cysteine residues in $\mathrm{I} \kappa \mathrm{B} \alpha$ kinase and NF- $\kappa$ B (p65) by xanthohumol leads to suppression of NF$\kappa \mathrm{B}$-regulated gene products and potentiation of apoptosis in leukemia cells," Blood, vol. 113, no. 9, pp. 2003-2013, 2009.

[71] C. Dorn, T. S. Weiss, J. Heilmann, and C. Hellerbrand, "Xanthohumol, a prenylated chalcone derived from hops, inhibits proliferation, migration and interleukin-8 expression of hepatocellular carcinoma cells," International Journal of Oncology, vol. 36, no. 2, pp. 435-441, 2010.

[72] C. Dorn, T. S. Weiss, J. Heilmann, and C. Hellerbrand, "Inhibitory and apoptosis-inducing effects of xanthohumol, a prenylated chalone present in hops, in human prostate cancer cells," Anticancer Research, vol. 30, no. 9, pp. 3333-3339, 2010.

[73] E. C. Colgate, C. L. Miranda, J. F. Stevens, T. M. Bray, and E. Ho, "Xanthohumol, a prenylflavonoid derived from hops induces apoptosis and inhibits NF-kappaB activation in prostate epithelial cells," Cancer Letters, vol. 246, no. 1-2, pp. 201-209, 2007.

[74] S. C. Cheah, D. R. Appleton, S. T. Lee, M. L. Lam, A. H. A. Hadi, and M. R. Mustafa, "Panduratin a inhibits the growth of A549 cells through induction of apoptosis and inhibition of NFKappaB translocation," Molecules, vol. 16, no. 3, pp. 2583-2598, 2011.

[75] E. Cavalieri, D. Chakravarti, J. Guttenplan et al., "Catechol estrogen quinones as initiators of breast and other human cancers: implications for biomarkers of susceptibility and cancer prevention," Biochimica et Biophysica Acta, vol. 1766, no. 1, pp. 63-78, 2006.

[76] K. Mokbel, "The evolving role of aromatase inhibitors in breast cancer," International Journal of Clinical Oncology, vol. 7, no. 5, pp. 279-283, 2002.

[77] Y. Wang, F. L. Chan, S. Chen, and L. K. Leung, "The plant polyphenol butein inhibits testosterone-induced proliferation in breast cancer cells expressing aromatase," Life Sciences, vol. 77, no. 1, pp. 39-51, 2005.

[78] M. Maggiolini, G. Statti, A. Vivacqua et al., "Estrogenic and antiproliferative activities of isoliquiritigenin in MCF7 breast cancer cells," Journal of Steroid Biochemistry and Molecular Biology, vol. 82, no. 4-5, pp. 315-322, 2002.

[79] M. Baba, R. Asano, I. Takigami et al., "Studies on cancer chemoprevention by traditional folk medicines XXV. Inhibitory effect of isoliquiritigenin on azoxymethane-induced murine colon aberrant crypt focus formation and carcinogenesis," Biological and Pharmaceutical Bulletin, vol. 25, no. 2, pp. 247250, 2002.

[80] Y. W. Chin, H. A. Jung, Y. Liu et al., "Anti-oxidant constituents of the roots and stolons of licorice (Glycyrrhiza glabra)," Journal of Agricultural and Food Chemistry, vol. 55, no. 12, pp. 4691-4697, 2007.

[81] T. Takahashi, N. Takasuka, M. Iigo et al., "Isoliquiritigenin, a flavonoid from licorice, reduces prostaglandin E2 and nitric oxide, causes apoptosis, and suppresses aberrant crypt foci development," Cancer Science, vol. 95, no. 5, pp. 448-453, 2004.

[82] M. Cuendet, J. Guo, Y. Luo et al., "Cancer chemopreventive activity and metabolism of isoliquiritigenin, a compound found in licorice," Cancer Prevention Research, vol. 3, no. 2, pp. 221232, 2010.

[83] B. Orlikova, D. Tasdemir, F. Golais, M. Dicato, and M. Diederich, "Dietary chalcones with chemopreventive and chemotherapeutic potential," Genes and Nutrition, vol. 6, no. 2, pp. 125-147, 2011.

[84] T. Yokozawa, E. J. Cho, D. Y. Rhyu, N. Shibahara, and K. Aoyagi, "Glycyrrhizae Radix attenuates peroxynitrite-induced renal oxidative damage through inhibition of protein nitration," Free Radical Research, vol. 39, no. 2, pp. 203-211, 2005.

[85] T. Akihisa, H. Tokuda, M. Ukiya et al., "Chalcones, coumarins, and flavanones from the exudate of Angelica keiskei and their chemopreventive effects," Cancer Letters, vol. 201, no. 2, pp. 133137, 2003.

[86] T. Akihisa, H. Tokuda, D. Hasegawa et al., "Chalcones and other compounds from the exudates of Angelica keiskei and their cancer chemopreventive effects," Journal of Natural Products, vol. 69, no. 1, pp. 38-42, 2006.

[87] H. Matsuda, S. Kiyohara, S. Sugimoto, S. Ando, S. Nakamura, and M. Yoshikawa, "Bioactive constituents from Chinese natural medicines. XXXIII. Inhibitors from the seeds of Psoralea corylifolia on production of nitric oxide in lipopolysaccharideactivated macrophages," Biological and Pharmaceutical Bulletin, vol. 32, no. 1, pp. 147-149, 2009.

[88] H. Haraguchi, J. Inoue, Y. Tamura, and K. Mizutani, "Antioxidative components of Psoralea corylifolia (Leguminosae)," Phytotherapy Research, vol. 16, no. 6, pp. 539-544, 2002.

[89] V. Kuete and L. P. Sandjo, "Isobavachalcone: an overview," Chinese Journal of Integrative Medicine, vol. 18, no. 7, pp. 543547, 2012.

[90] C. Gerhäuser, A. P. Alt, K. Klimo, J. Knauft, N. Frank, and H. Becker, "Isolation and potential cancer chemopreventive activities of phenolic compounds of beer," Phytochemistry Reviews, vol. 1, no. 3, pp. 369-377, 2002.

[91] P. Kaur, S. Kaur, N. Kumar, B. Singh, and S. Kumar, "Evaluation of antigenotoxic activity of isoliquiritin apioside from Glycyrrhiza glabra L," Toxicology in Vitro, vol. 23, no. 4, pp. 680686, 2009.

[92] S. Monteghirfo, F. Tosetti, C. Ambrosini et al., "Antileukemia effects of xanthohumol in Bcr/Abl-transformed cells involve nuclear factor- $\kappa \mathrm{B}$ and p53 modulation," Molecular Cancer Therapeutics, vol. 7, no. 9, pp. 2692-2702, 2008.

[93] J. I. Jung, E. Chung, M. R. Seon et al., "Isoliquiritigenin (ISL) inhibits ErbB3 signaling in prostate cancer cells," BioFactors, vol. 28, no. 3-4, pp. 159-168, 2006.

[94] H. Jing, X. Zhou, X. Dong et al., "Abrogation of Akt signaling by Isobavachalcone contributes to its anti-proliferative effects towards human cancer cells," Cancer Letters, vol. 294, no. 2, pp. 167-177, 2010.

[95] M. K. Pandey, S. Bokyung, S. A. Kwang, and B. B. Aggarwal, "Butein suppresses constitutive and inducible signal transducer and activator of transcription (stat) 3 activation and stat3regulated gene products through the induction of a protein tyrosine phosphatase SHP-1," Molecular Pharmacology, vol. 75, no. 3, pp. 525-533, 2009. 
[96] T. Yagura, T. Motomiya, M. Ito et al., "Anticarcinogenic compounds in the Uzbek medicinal plant, Helichrysum maracandicum," Journal of Natural Medicines, vol. 62, no. 2, pp. 174-178, 2008.

[97] A. M. Puebla-Perez, R. A. Herrera-Hernandez, M. M. Villasenor-Garcia et al., "Effect of isocordoin in the release of TGF- $\beta 1$ of mice with L5178Y lymphoma," in Proceedings of the 13th International Congress of Immunology, pp. 167-171, Rio de Janeiro, Brazil, 2007.

[98] S. Guerreiro, R. Monteiro, M. J. Martins, C. Calhau, I. Azevedo, and R. Soares, "Distinct modulation of alkaline phosphatase isoenzymes by $17 \beta$-estradiol and xanthohumol in breast cancer MCF-7 cells," Clinical Biochemistry, vol. 40, no. 3-4, pp. 268273, 2007.

[99] M. Mareel, M. Bracke, and F. Van Roy, "Invasion promoter versus invasion suppressor molecules: the paradigm of Ecadherin," Molecular Biology Reports, vol. 19, no. 1, pp. 45-67, 1994.

[100] C. Wittekind and M. Neid, "Cancer invasion and metastasis," Oncology, vol. 69, supplement 1, pp. 14-16, 2005.

[101] B. Vanhoecke, L. Derycke, V. Van Marck, H. Depypere, D. De Keukeleire, and M. Bracke, "Antiinvasive effect of xanthohumol, a prenylated chalcone present in hops (Humulus lupulus L.) and beer," International Journal of Cancer, vol. 117, no. 6, pp. 889-895, 2005.

[102] M. E. Bracke, B. W. A. Vanhoecke, L. Derycke et al., "Plant polyphenolics as anti-invasive cancer agents," Anti-Cancer Agents in Medicinal Chemistry, vol. 8, no. 2, pp. 171-185, 2008.

[103] S. Lust, B. Vanhoecke, M. Van Gele et al., "Xanthohumol activates the proapoptotic arm of the unfolded protein response in chronic lymphocytic leukemia," Anticancer Research, vol. 29, no. 10, pp. 3797-3805, 2009.

[104] R. Benelli, R. Venè, M. Ciarlo, S. Carlone, O. Barbieri, and N. Ferrari, "The AKT/NF- $\kappa$ B inhibitor xanthohumol is a potent anti-lymphocytic leukemia drug overcoming chemoresistance and cell infiltration," Biochemical Pharmacology, vol. 83, no. 12, pp. 1634-1642, 2012.

[105] B. Ngameni, M. Touaibia, R. Patnam et al., "Inhibition of MMP2 secretion from brain tumor cells suggests chemopreventive properties of a furanocoumarin glycoside and of chalcones isolated from the twigs of Dorstenia turbinata," Phytochemistry, vol. 67, no. 23, pp. 2573-2579, 2006.

[106] B. Ngameni, M. Touaibia, A. Belkaid et al., "Inhibition of matrix metalloproteinase- 2 secretion by chalcones from the twigs of Dorstenia barteri Bureau," Arkivoc, vol. 2007, no. 9, pp. 91-103, 2007.

[107] Y. Kimura and K. Baba, "Antitumor and antimetastatic activities of Angelica keiskei roots, part 1: isolation of an active substance, xanthoangelol," International Journal of Cancer, vol. 106, no. 3 , pp. 429-437, 2003.

[108] Y. Kimura, M. Taniguchi, and K. Baba, "Antitumor and antimetastatic activities of 4-hydroxyderricin isolated from Angelica keiskei roots," Planta Medica, vol. 70, no. 3, pp. 211-219, 2004.

[109] S. Yamazaki, T. Morita, H. Endo et al., "Isoliquiritigenin suppresses pulmonary metastasis of mouse renal cell carcinoma," Cancer Letters, vol. 183, no. 1, pp. 23-30, 2002.

[110] S. Maddika, S. R. Ande, S. Panigrahi et al., "Cell survival, cell death and cell cycle pathways are interconnected: implications for cancer therapy," Drug Resistance Updates, vol. 10, no. 1-2, pp. 13-29, 2007.
[111] J. M. Yun, M. H. Kweon, H. Kwon, J. K. Hwang, and H. Mukhtar, "Induction of apoptosis and cell cycle arrest by a chalcone panduratin A isolated from Kaempferia pandurata in androgenindependent human prostate cancer cells PC3 and DU145," Carcinogenesis, vol. 27, no. 7, pp. 1454-1464, 2006.

[112] M. Kanazawa, Y. Satomi, Y. Mizutani et al., "Isoliquiritigenin inhibits the growth of prostate cancer," European Urology, vol. 43, no. 5, pp. 580-586, 2003.

[113] G. S. Zhou, L. J. Song, and B. Yang, "Isoliquiritigenin inhibits proliferation and induces apoptosis of U87 human glioma cells in vitro," Molecular Medicine Reports, vol. 7, no. 2, pp. 531-536, 2012.

[114] T. Ii, Y. Satomi, D. Katoh et al., "Induction of cell cycle arrest and p21CIP1/WAF1 expression in human lung cancer cells by isoliquiritigenin," Cancer Letters, vol. 207, no. 1, pp. 27-35, 2004.

[115] Y. L. Hsu, P. L. Kuo, L. C. Chiang, and C. C. Lin, "Isoliquiritigenin inhibits the proliferation and induces the apoptosis of human non-small cell lung cancer A549 cells," Clinical and Experimental Pharmacology and Physiology, vol. 31, no. 7, pp. 414-418, 2004.

[116] Y. L. Hsu, P. L. Kuo, and C. C. Lin, "Isoliquiritigenin induces apoptosis and cell cycle arrest through p53-dependent pathway in Hep G2 cells," Life Sciences, vol. 77, no. 3, pp. 279-292, 2005.

[117] Y. K. Rao, S. H. Fang, and Y. M. Tzeng, "Differential effects of synthesized $2^{\prime}$-oxygenated chalcone derivatives: modulation of human cell cycle phase distribution," Bioorganic and Medicinal Chemistry, vol. 12, no. 10, pp. 2679-2686, 2004.

[118] Y. K. Rao, T. Y. Kao, J. L. Ko, and Y. M. Tzeng, "Chalcone HTMC causes in vitro selective cytotoxicity, cell-cycle G 1 phase arrest through p53-dependent pathway in human lung adenocarcinoma A549 cells, and in vivo tumor growth suppression," Bioorganic and Medicinal Chemistry Letters, vol. 20, no. 22, pp. 6508-6512, 2010.

[119] Y. Fu, T. C. Hsieh, J. Guo et al., "Licochalcone-A, a novel flavonoid isolated from licorice root (Glycyrrhiza glabra), causes G2 and late-G1 arrests in androgen-independent PC-3 prostate cancer cells," Biochemical and Biophysical Research Communications, vol. 322, no. 1, pp. 263-270, 2004.

[120] X. F. Zhu, B. F. Xie, J. M. Zhou et al., "Blockade of vascular endothelial growth factor receptor signal pathway and antitumor activity of ON-III $\left(2^{\prime}, 4^{\prime}\right.$-dihydroxy- $6^{\prime}$-methoxy$3^{\prime}, 5^{\prime}$-dimethylchalcone), a component from Chinese herbal medicine," Molecular Pharmacology, vol. 67, no. 5, pp. 14441450, 2005.

[121] J. Mojzis, L. Varinska, G. Mojzisova, I. Kostova, and L. Mirossay, "Antiangiogenic effects of flavonoids and chalcones," Pharmacological Research, vol. 57, no. 4, pp. 259-265, 2008.

[122] C. Gerhäuser, "Beer constituents as potential cancer chemopreventive agents," European Journal of Cancer, vol. 41, no. 13, pp. 1941-1954, 2005.

[123] A. Albini, R. Dell'Eva, R. Vené et al., "Mechanisms of the antiangiogenic activity by the hop flavonoid xanthohumol: NF$\kappa \mathrm{B}$ and Akt as targets," FASEB Journal, vol. 20, no. 3, pp. 527-529, 2006.

[124] R. Dell'Eva, C. Ambrosini, N. Vannini, G. Piaggio, A. Albini, and N. Ferrari, "AKT/NF- $\kappa$ B inhibitor xanthohumol targets cell growth and angiogenesis in hematologic malignancies," Cancer, vol. 110, no. 9, pp. 2007-2011, 2007.

[125] R. Negrão, J. Incio, R. Lopes, I. Azevedo, and R. Soares, "Evidence for the effects of xanthohumol in disrupting angiogenic, but not stable vessels," International Journal of Biomedical Science, vol. 3, no. 4, pp. 279-286, 2007. 
[126] D. Li, Z. Wang, H. Chen et al., "Isoliquiritigenin induces monocytic differentiation of HL-60 cells," Free Radical Biology and Medicine, vol. 46, no. 6, pp. 731-736, 2009.

[127] C. K. Lee, S. H. Son, K. K. Park, J. H. Y. Park, S. S. Lim, and W. Y. Chung, "Isoliquiritigenin inhibits tumor growth and protects the kidney and liver against chemotherapy-induced toxicity in a mouse xenograft model of colon carcinoma," Journal of Pharmacological Sciences, vol. 106, no. 3, pp. 444-451, 2008.

[128] M. Samoszuk, J. Tan, and G. Chorn, "The chalcone butein from Rhus verniciflua Stokes inhibits clonogenic growth of human breast cancer cells co-cultured with fibroblasts," $B M C$ Complementary and Alternative Medicine, vol. 5, article 5, 2005.

[129] H. Nozaki, K. I. Hayashi, M. Kido et al., "Pauferrol A, a novel chalcone trimer with a cyclobutane ring from Caesalpinia ferrea mart exhibiting DNA topoisomerase II inhibition and apoptosis-inducing activity," Tetrahedron Letters, vol. 48, no. 47, pp. 8290-8292, 2007.

[130] P. Krishnan and K. F. Bastow, "Novel mechanism of cellular DNA topoisomerase II inhibition by the pyranonaphthoquinone derivatives $\alpha$-lapachone and $\beta$-lapachone," Cancer Chemotherapy and Pharmacology, vol. 47, no. 3, pp. 187-198, 2001. 


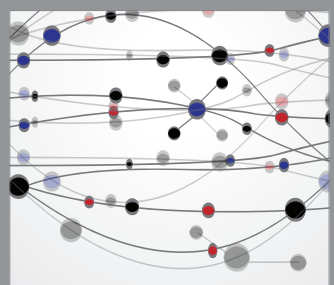

The Scientific World Journal
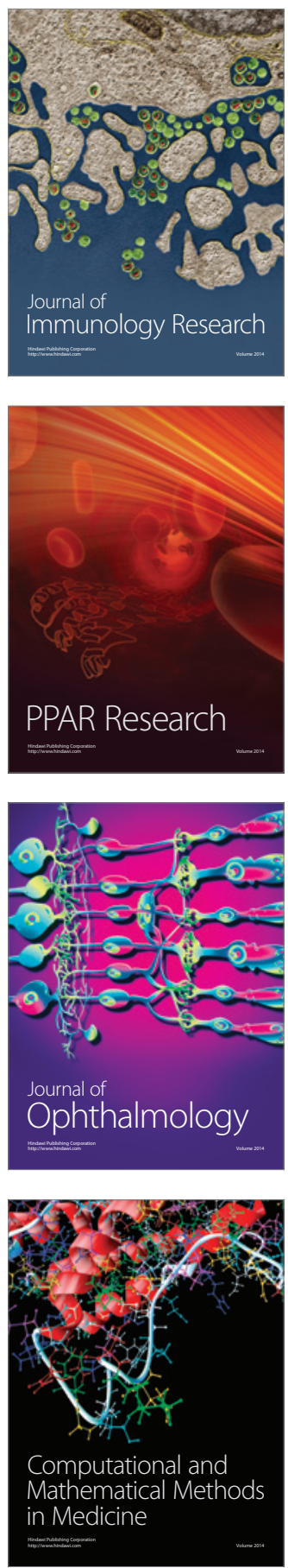



Gastroenterology

Research and Practice
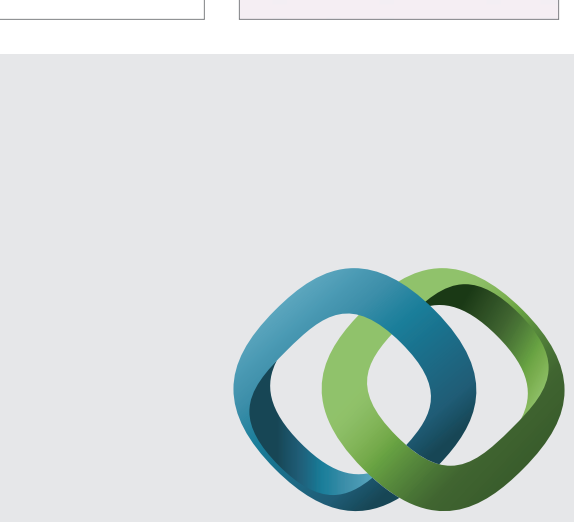

\section{Hindawi}

Submit your manuscripts at

http://www.hindawi.com
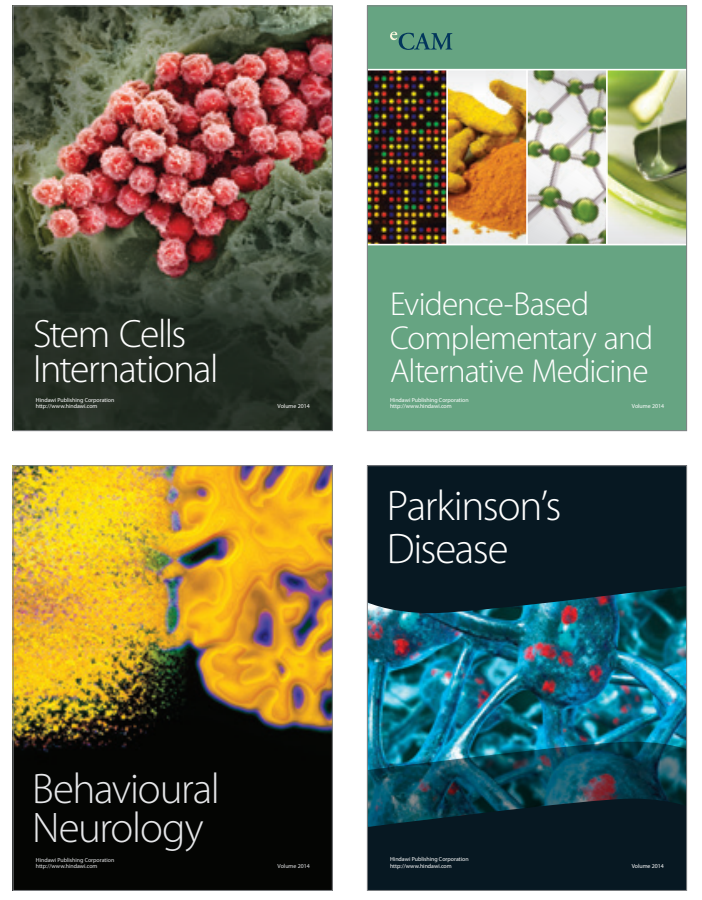
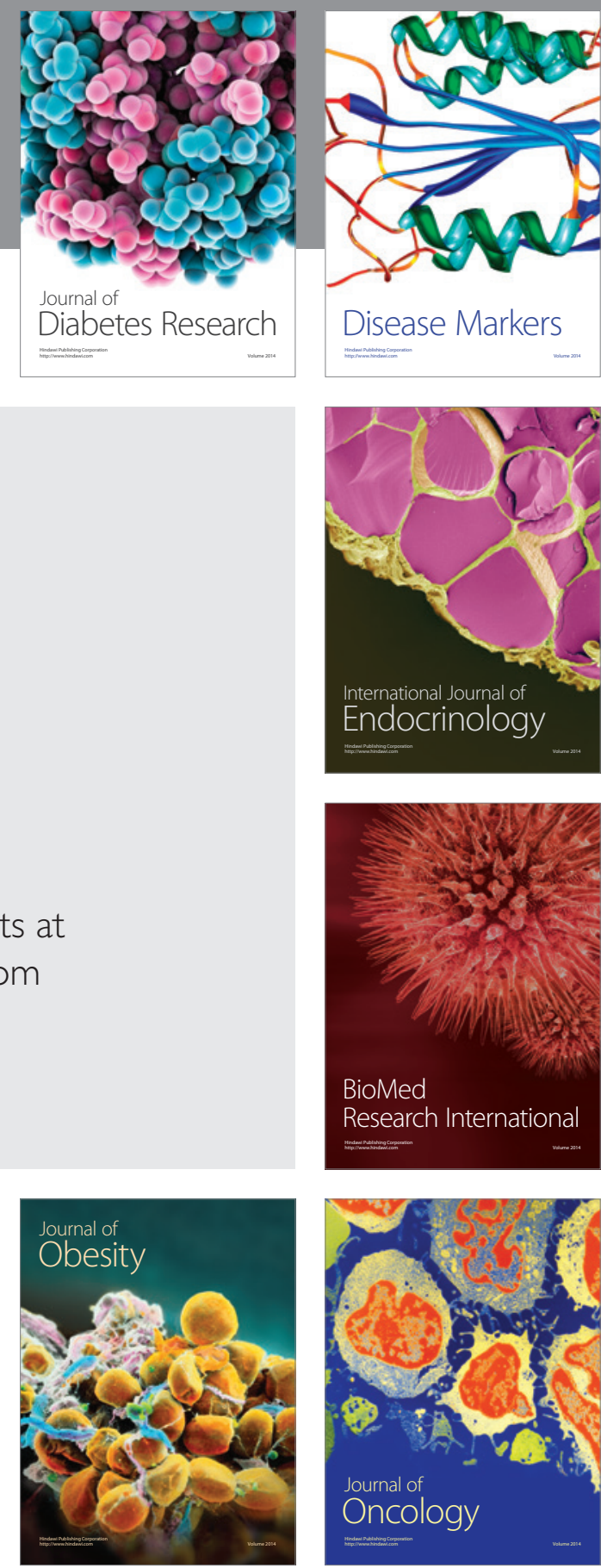

Disease Markers
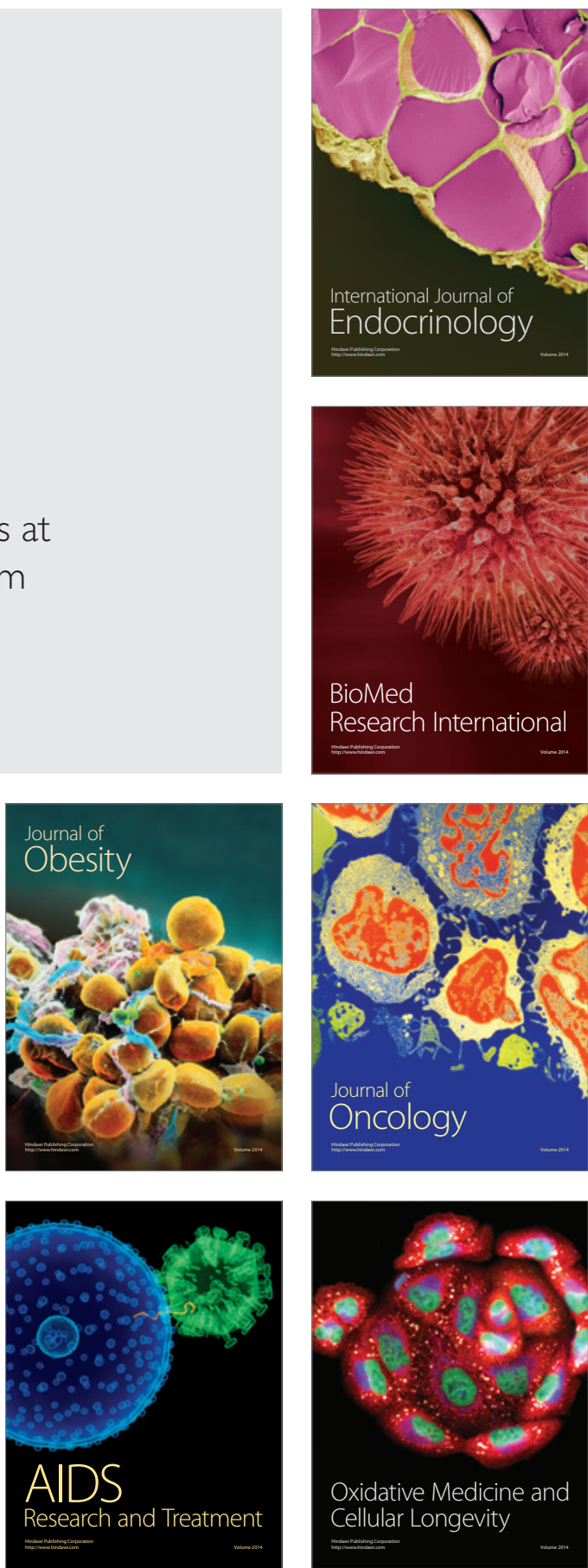